\title{
The future of vitamin D analogs
}

\section{Carlien Leyssens, Lieve Verlinden and Annemieke Verstuyf*}

Clinical and Experimental Endocrinology, Department of Clinical and Experimental Medicine, KU Leuven, Leuven, Belgium

\section{Edited by:}

Carsten Carlberg, University of

Eastern Finland, Finland

Reviewed by:

Ferdinand Molnár, University of

Eastern Finland, Finland

Antonio Mourino, Universidad de

Santiago, Spain

*Correspondence:

Annemieke Verstuyf, Clinical and Experimental Endocrinology,

Department of Clinical and

Experimental Medicine, KU Leuven,

Herestraat 49, bus 902 ,

3000 Leuven, Belgium

e-mail: mieke.verstuyf@

med.kuleuven.be
The active form of vitamin $D_{3}, 1,25$-dihydroxyvitamin $D_{3}$, is a major regulator of bone and calcium homeostasis. In addition, this hormone also inhibits the proliferation and stimulates the differentiation of normal as well as malignant cells. Supraphysiological doses of 1,25-dihydroxyvitamin $D_{3}$ are required to reduce cancer cell proliferation. However, these doses will lead in vivo to calcemic side effects such as hypercalcemia and hypercalciuria. During the last 25 years, many structural analogs of 1,25-dihydroxyvitamin $\mathrm{D}_{3}$ have been synthesized by the introduction of chemical modifications in the A-ring, central CD-ring region or side chain of 1,25-dihydroxyvitamin $D_{3}$ in the hope to find molecules with a clear dissociation between the beneficial antiproliferative effects and adverse calcemic side effects. One example of such an analog with a good dissociation ratio is calcipotriol (Daivonex ${ }^{\circledR}$ ), which is clinically used to treat the hyperproliferative skin disease psoriasis. Other vitamin $D$ analogs were clinically approved for the treatment of osteoporosis or secondary hyperparathyroidism. No vitamin D analog is currently used in the clinic for the treatment of cancer although several analogs have been shown to be potent drugs in animal models of cancer. Transcriptomics studies as well as in vitro cell biological experiments unraveled basic mechanisms involved in the antineoplastic effects of vitamin $D$ and its analogs. 1,25-dihydroxyvitamin $D_{3}$ and analogs act in a cell type- and tissue-specific manner. Moreover, a blockade in the transition of the G0/1 toward $S$ phase of the cell cycle, induction of apoptosis, inhibition of migration and invasion of tumor cells together with effects on angiogenesis and inflammation have been implicated in the pleiotropic effects of 1,25-dihydroxyvitamin $D_{3}$ and its analogs. In this review we will give an overview of the action of vitamin $D$ analogs in tumor cells and look forward how these compounds could be introduced in the clinical practice.

Keywords: vitamin D, analogs, pleiotropic effects, cancer

\section{INTRODUCTION}

The active form of vitamin $\mathrm{D}_{3}, 1,25$-dihydroxyvitamin $\mathrm{D}_{3}$ $\left[1 \alpha, 25(\mathrm{OH})_{2} \mathrm{D}_{3} ; \mathbf{1}\right]$ (Table $\mathbf{1}$ ), is mostly known for its effects on bone, calcium, and phosphate homeostasis. Next to these classical effects, $1,25(\mathrm{OH})_{2} \mathrm{D}_{3}$ also exerts so-called non-classical effects on various tissues which express the vitamin $\mathrm{D}$ receptor (VDR) as well as the enzymes that are responsible for activating the hydroxylations of vitamin $\mathrm{D}_{3}$, which is essential for the formation of $1,25(\mathrm{OH})_{2} \mathrm{D}_{3}$. Thus, most tissues have the ability to convert vitamin $\mathrm{D}_{3}$ into its active form, $1,25(\mathrm{OH})_{2} \mathrm{D}_{3}$, which in turn will bind the VDR in order to positively or negatively influence target genes via binding of the $1,25(\mathrm{OH})_{2} \mathrm{D}_{3} / \mathrm{VDR}$ complex to vitamin $\mathrm{D}$ receptor elements (VDRE). Non-classical properties of $1,25(\mathrm{OH})_{2} \mathrm{D}_{3}$ include prodifferentiating and antiproliferative effects on normal and cancer cells (Colston et al., 1981; Jensen et al., 2001) as well as immunomodulatory effects. However, in order to obtain these non-classical effects, $1,25(\mathrm{OH})_{2} \mathrm{D}_{3}$ doses of the nanomolar range are necessary, while physiological $1,25(\mathrm{OH})_{2} \mathrm{D}_{3}$ serum concentrations are in the picomolar range. Since supraphysiological doses of $1,25(\mathrm{OH})_{2} \mathrm{D}_{3}$ result in hypercalcemia, $1,25(\mathrm{OH})_{2} \mathrm{D}_{3}$ analogs were developed to minimize the calcemic side effects while preserving or augmenting the beneficial effects of $1,25(\mathrm{OH})_{2} \mathrm{D}_{3}$. Both industry and academic institutions have synthesized a vast amount of vitamin $\mathrm{D}$ analogs. Some of these analogs have tissue-specific effects with low calcemic side effects and can be given at higher doses compared to the mother compound.

\section{CLINICALLY APPROVED VITAMIN D ANALOGS}

Given the huge amount of vitamin D analogs that have been synthesized during the years, it is nearly impossible to give an overview of them all. In the first part we will discuss vitamin D analogs that are clinically approved (Table 2). For several conditions such as secondary hyperparathyroidism, psoriasis and osteoporosis, vitamin D analogs are frequently used as a treatment option. Paricalcitol [2] and doxercalciferol [3] are vitamin $\mathrm{D}_{2}$ analogs approved for therapeutic use of secondary hyperparathyroidism. In Japan falecalcitriol [4] and maxacalcitol [5] are also used to treat this disease. Secondary hyperparathyroidism is characterized by elevated parathyroid hormone (PTH) levels in response to hypocalcemia and is often caused by chronic kidney disease. Above-mentioned vitamin D analogs suppress PTH, as does $1,25(\mathrm{OH})_{2} \mathrm{D}_{3}$, but without inducing severe hypercalcemia. Clinical studies with chronic kidney disease patients show that different analogs induce a stronger PTH suppression compared to placebo treatment (Hamdy et al., 1995; Coburn et al., 2004; Coyne et al., 2006). Also, end-stage renal disease patients treated with these analogs often have a better survival (Teng et al., 2003; 
Table 1 | Overview of vitamin D analogs.

\begin{tabular}{l}
$\begin{array}{l}\text { Identification } \\
\text { number }\end{array}$ \\
\hline $1 \alpha, 25(\mathrm{OH})_{2} \mathrm{D}_{3}$
\end{tabular}

[2]

Paricalcitol

(19-nor-1 $\left.\alpha, 25(\mathrm{OH})_{2} \mathrm{D}_{2}\right)$
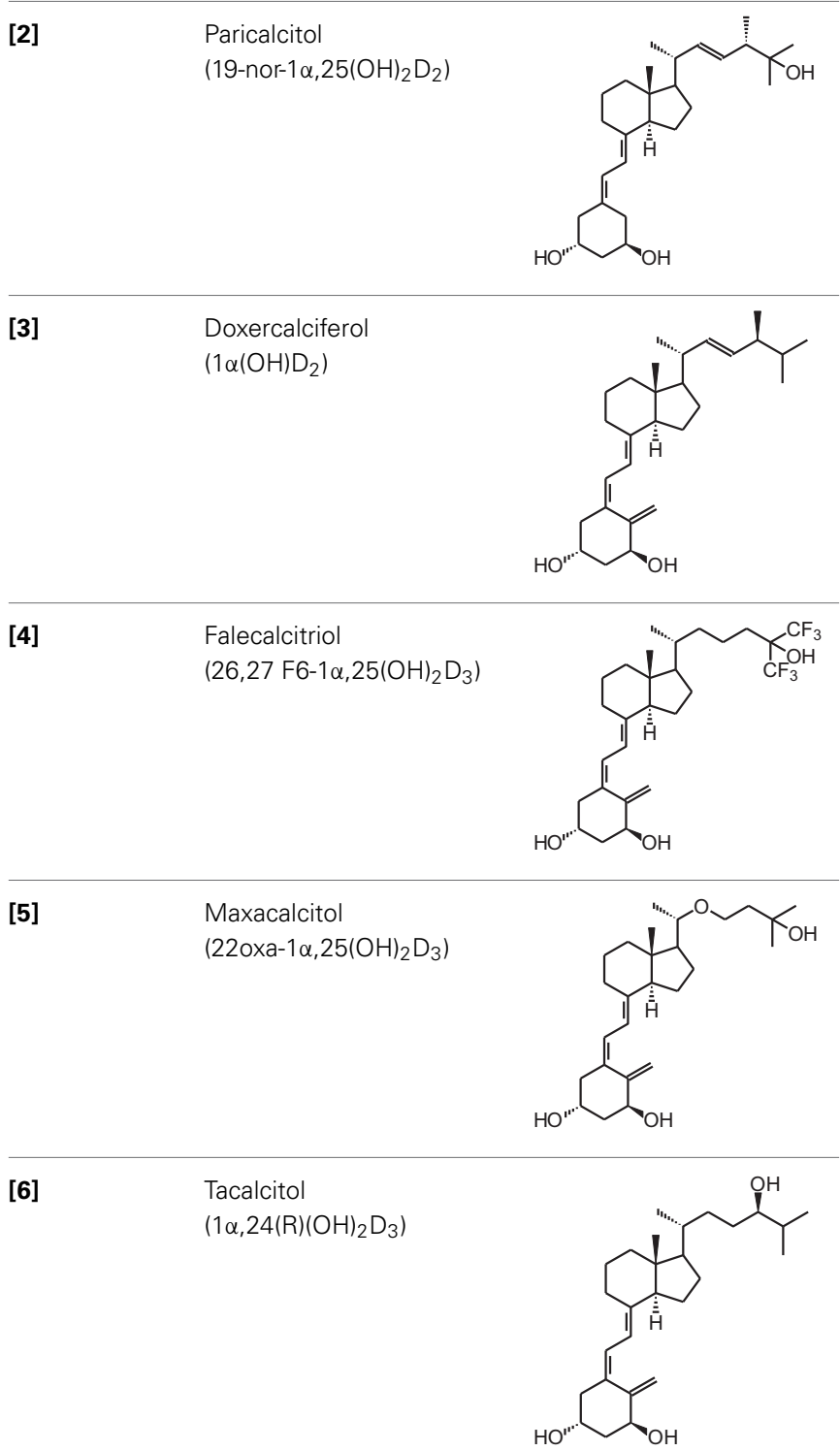

[7] $\begin{aligned} & \text { Calcipotriol } \\ & (22-e n e-26,27-d e h y d r o- \\ & \left.1 \alpha, 25(\mathrm{OH})_{2} \mathrm{D}_{3}\right)\end{aligned}$

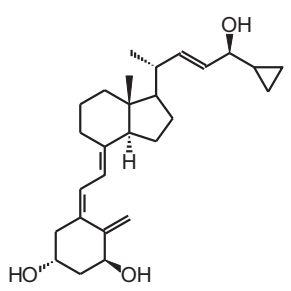

(Continued)
Table 1 | Continued

\begin{tabular}{ll}
\hline $\begin{array}{l}\text { Identification } \\
\text { number }\end{array}$ & Name \\
\hline$[8]$ & $\begin{array}{l}\text { Alfacalcidol } \\
\left(1 \alpha(\mathrm{OH}) \mathrm{D}_{3}\right)\end{array}$ \\
& \\
& \\
\end{tabular}

Structure

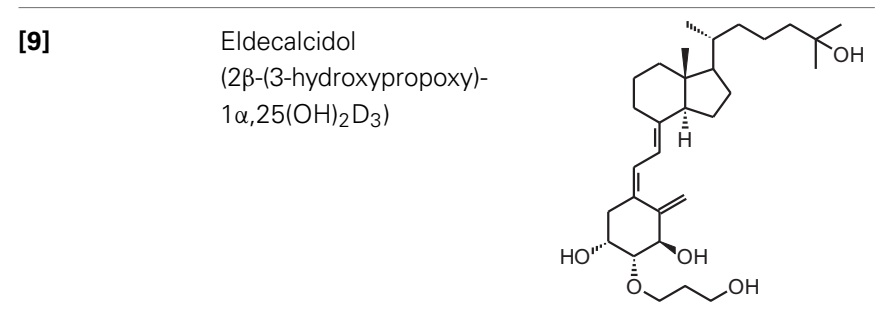<smiles>C=C1/C(=C\C=C2/CCCCC2(C)C2CCC(CCCCC(C)C)C2C)C[C@@H](O)C[C@@H]1O</smiles>

Seocalcitol (22,24-diene-24,26,27trishomo- $\left.1 \alpha, 25(\mathrm{OH})_{2} \mathrm{D}_{3}\right)$

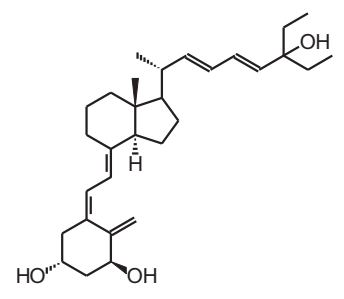

[11]

20-epi- $1 \alpha, 25(\mathrm{OH})_{2} \mathrm{D}_{3}$<smiles>C=C1/C(=C\C=C2/CCCCC2(C)C2CCC(CCCC(C)(C)O)C2C)C[C@@H](O)C[C@@H]1O</smiles>

[12]

Lexicalcitol (20-epi-22-oxa-24,26,27trishomo- $1 \alpha, 25(\mathrm{OH})_{2} \mathrm{D}_{3}$ )

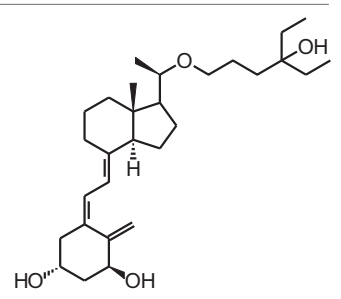

[13]

CD578

(17-methyl-19-nor-21-nor23-yne-26,27-F6-

$\left.1 \alpha, 25(\mathrm{OH})_{2} \mathrm{D}_{3}\right)$

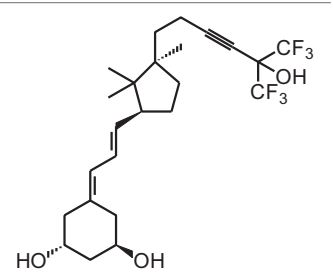

[14]
Inecalcitol
(19-nor-14-epi-23-yne-
$\left.1 \alpha, 25(\mathrm{OH})_{2} \mathrm{D}_{3}\right)$

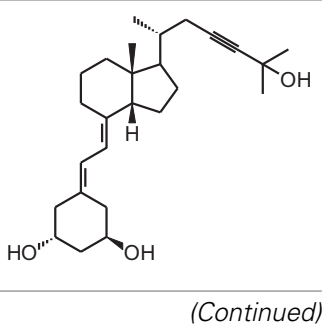


Table 1 | Continued

\begin{tabular}{|c|c|c|}
\hline $\begin{array}{l}\text { Identification } \\
\text { number }\end{array}$ & Name & Structure \\
\hline [15] & $\begin{array}{l}\text { TX527 } \\
(19-\text {-nor-14,20-bisepi-23- } \\
\left.\text { yne-1 } \alpha, 25(\mathrm{OH})_{2} \mathrm{D}_{3}\right)\end{array}$ & \\
\hline [16] & $\begin{array}{l}2 \mathrm{MD} \\
\text { (2-methylene-19-nor-(20S)- } \\
\left.1 \alpha, 25(\mathrm{OH})_{2} \mathrm{D}_{3}\right)\end{array}$ & \\
\hline
\end{tabular}

[17] $\begin{aligned} & \mathrm{WY} 1112 \\ & \text { (Seco-C-9,11-bisnor-17- } \\ & \text { methyl-20-epi-26,27-F6- } \\ & \left.1 \alpha, 25(\mathrm{OH})_{2} \mathrm{D}_{3}\right)\end{aligned}$

[18] $\begin{aligned} & \begin{array}{l}\mathrm{PRI}-2205 \\ ((5 \mathrm{E}, 7 \mathrm{E})-22-e n e-26,27- \\ \left.\text { dehydro-1 } 2,25(\mathrm{OH})_{2} \mathrm{D}_{3}\right)\end{array} \\ & \text { [19] } \\ & \left(12,25(\mathrm{OH})_{2} \mathrm{D}_{3}\right)\end{aligned}$

Tentori et al., 2006; Shinaberger et al., 2008). However, few studies with chronic kidney disease and end-stage renal disease patients directly compare the effects of $1,25(\mathrm{OH})_{2} \mathrm{D}_{3}$ with its analogs.

Psoriasis, a hyperproliferative condition of the skin, is also treated with vitamin D analogs. Tacalcitol [6], calcipotriol [7] and the recently approved maxacalcitol [5] are used either as monotherapy or in combination with topical steroids such as betamethasone dipropionate to treat psoriasis. The analogs exert prodifferentiating and antiproliferative effects on keratinocytes and also possess important anti-inflammatory properties. Furthermore, alfacalcidol $\left(\left[1 \alpha(\mathrm{OH}) \mathrm{D}_{3} ; 8\right]\right.$, actually a pre-metabolite of $\left.1,25(\mathrm{OH})_{2} \mathrm{D}_{3}\right)$ and eldecalcitol (ED-71) [9] are used in Japan in the treatment of osteoporosis. The recently approved eldecalcitol [9] is more effective than $1,25(\mathrm{OH})_{2} \mathrm{D}_{3}$ and alfacalcidol [8] in increasing bone mineral density and mechanical strength in ovariectomized rats (Uchiyama et al., 2002). Various studies in mouse models as well as in patients show that treatment with eldecalcitol [9] leads to higher lumbar and hip bone mineral density and a lower incidence of new vertebral fractures (Ito et al., 2011; Matsumoto et al., 2011; Harada et al., 2012; Hagino et al., 2013), making eldecalcitol [9] a very promising new analog for the treatment of osteoporosis.

\section{GENOME- AND TRANSCRIPTOME-WIDE EFFECTS OF VITAMIN D ANALOGS}

The exact mechanism of action of vitamin D analogs still has to be deciphered. The reason why specific analogs have superagonistic actions on specific tissues remains unknown, however several studies have tried to elucidate the mechanisms behind these tissue-specific effects. The catabolism of vitamin D analogs is one of the mechanisms that have an effect on their potency. Modifications of the side chain of $1,25(\mathrm{OH})_{2} \mathrm{D}_{3}$ are known to slow down its catabolism by CYP24A1 (Jones, 1997). Seocalcitol (EB1089) [10] and 20-epi-1,25(OH $)_{2} \mathrm{D}_{3}[\mathbf{1 1}]$ are degraded slower compared to $1,25(\mathrm{OH})_{2} \mathrm{D}_{3}$ leading to a longer exposure of these analogs to the tissues (Hansen and Maenpaa, 1997; Kissmeyer et al., 1997; Shankar et al., 1997; Zella et al., 2009). The metabolites formed after catabolism of lexicalcitol [12] are more active than the ones formed after $1,25(\mathrm{OH})_{2} \mathrm{D}_{3}$ is catabolized (Dilworth et al., 1997) and this analog is also more effective in slowing down the degradation rate of the VDR (van den Bemd et al., 1996). Moreover, since some cell types prefer specific catabolism pathways and enzymes above others, the degradation process may also contribute to the tissue-specific activity of vitamin $\mathrm{D}$ analogs. The affinity for the vitamin D binding protein (DBP) also plays a role in the activity of vitamin D analogs. Maxacalcitol [5] for example has a 500 times lower affinity for DBP and is thus cleared faster from the circulation than $1,25(\mathrm{OH})_{2} \mathrm{D}_{3}$ (Okano et al., 1989a). This analog has a short effect on bone and intestine, tissues responsible for calcium homeostasis, and a longer effect on PTH levels, making this analog ideal for the treatment of secondary hyperparathyroidism. However, it is still unknown why the duration of the effects is different in these tissues. Eldecalcitol [9] on the other hand has a higher DBP affinity compared to the mother compound, leading to longer sustained plasma levels and is thus more suitable for the treatment of osteoporosis (Okano et al., 1989b).

Another mechanism that contributes to the superagonistic effects of vitamin $\mathrm{D}$ analogs is their interaction with the VDR, co-activators and VDREs. 20-epi-1,25(OH $)_{2} \mathrm{D}_{3}$, a C-20 epimer of $1,25(\mathrm{OH})_{2} \mathrm{D}_{3}[\mathbf{1 1}]$, promotes heterodimerization between VDR and retinoid X receptor (RXR) (Liu et al., 2001). 20-epi$1,25(\mathrm{OH})_{2} \mathrm{D}_{3}[\mathbf{1 1}]$ and other analogs like maxacalcitol [5], CD578 [13], inecalcitol [14], and TX527 [15] require lower concentrations to recruit specific coactivators to the VDR/RXR/VDRE complex (Liu et al., 2000; Eelen et al., 2005, 2008; Schwinn and DeLuca, 2007). Approximately 10- fold lower doses of inecalcitol [14] and TX527 [15] are needed, compared to $1,25(\mathrm{OH})_{2} \mathrm{D}_{3}$, to acquire the same amount of co-activator interactions (Eelen et al., 
Table 2 | Overview of clinically approved vitamin D analogs.

\begin{tabular}{lll}
\hline Name & Structure & Indication
\end{tabular}

Paricalcitol (19-nor-1 $\left.\alpha, 25(\mathrm{OH})_{2} \mathrm{D}_{2}\right)$<smiles>CC(/C=C/C(C)C(C)(C)O)C1CCC2/C(=C/C=C3CC(O)CC(O)C3)CCCC21C</smiles>

Secondary hyperparathyroidism $\quad$ Zemplar $^{\circledR}$ (Abbott)

$\mathrm{HO} \times \mathrm{OH}$

Doxercalciferol $\left(1 \alpha(\mathrm{OH}) \mathrm{D}_{2}\right)$<smiles>C=C1/C(=C\C=C2/CCCC3C(C)/C(=C/C(C)C(C)C)CCC23C)C[C@@H](O)CC1O</smiles>

$\mathrm{HO}^{\prime \prime}$

\section{Falecalcitriol $(26,27$ \\ F6- $1 \alpha, 25(\mathrm{OH})_{2} \mathrm{D}_{3}$ )}

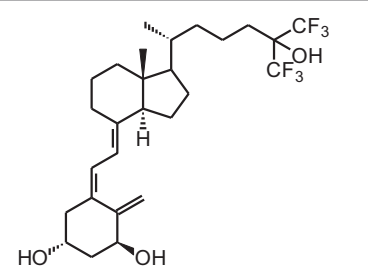

$\mathrm{HO} \sim \mathrm{OH}$
Secondary hyperparathyroidism

(Japan only)
Fulstan ${ }^{\circledR}$ (Dainippon Sumitomo) and Hornel ${ }^{\circledR}$ (Taisho Yakuhin)

\section{Maxacalcitol}

(22oxa-1 $\left.\alpha, 25(\mathrm{OH})_{2} \mathrm{D}_{3}\right)$

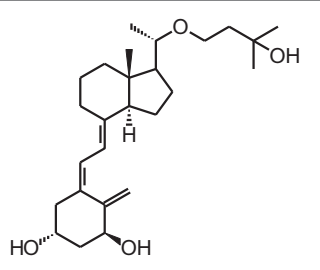

Secondary hyperparathyroidism and psoriasis (Japan only)
Oxarol $^{\circledR}$ (Chugai Pharmaceutical)

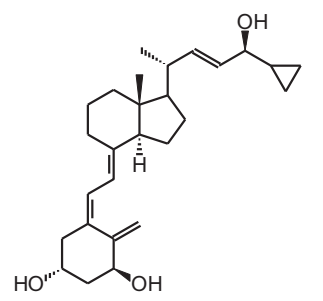

Psoriasis

Calcipotriol (22-ene-26,27-

dehydro- $\left.1 \alpha, 25(\mathrm{OH})_{2} \mathrm{D}_{3}\right)$

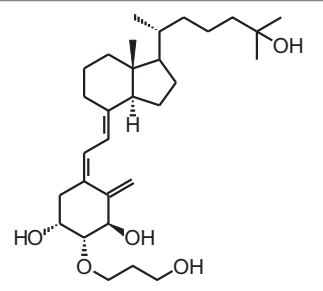

Eldecalcitol

(2ß-(3-hydroxypropoxy)-

$\left.1 \alpha, 25(\mathrm{OH})_{2} \mathrm{D}_{3}\right)$
Osteoporosis (Japan only)

Edirol $^{\circledR}$ (Chugai Pharmaceutical)
Daivonex ${ }^{\circledR}$, Dovonex ${ }^{\circledR}$ (LEO

Pharma), Sorilux ${ }^{\circledR}$ (Stiefel) 
2005). Vitamin D analogs might also be able to induce tissuespecific effects by favoring binding to specific VDRE motifs in target gene promoters. Analogs with a 20-methyl group as well as seocalcitol [10] bound to a VDR/RXR complex preferably interact with the IP9 type of VDRE (Danielsson et al., 1996; Quack and Carlberg, 1999).

On the genome level, studies using chromatin immunoprecipitation (ChIP) and micro-array techniques have investigated $1,25(\mathrm{OH})_{2} \mathrm{D}_{3}$-regulated genes in different cell lines. One ChIP study compared the binding sites of the VDR in intestinal tissue after $1,25(\mathrm{OH})_{2} \mathrm{D}_{3}$ or 20-epi-1,25(OH $)_{2} \mathrm{D}_{3}$ [11] treatment. This study shows that both $1,25(\mathrm{OH})_{2} \mathrm{D}_{3}$ and 20 -epi-1,25(OH $)_{2} \mathrm{D}_{3}$ [11] induce VDR binding to CYP24A1 and TRPV6 loci in the intestine, but the analog elicits a prolonged VDR binding to these genes leading to its superagonistic characteristics such as hypercalcemia in vivo (Zella et al., 2009). Other ChIP studies have tried to investigate the molecular mechanisms of some analogs in different tissues. In osteoblast cell models 2MD [16] bound to the VDR is able to bind VDREs at lower concentrations compared to $1,25(\mathrm{OH})_{2} \mathrm{D}_{3}$ (Yamamoto et al., 2003). Seocalcitol [10], on the other hand, mediates the dissociation of Williams syndrome transcription factor of the aromatase promoter leading to inhibition of aromatase expression and activity in breast cancer cells which is one of the main therapeutic strategies in breast cancer patients (Lundqvist et al., 2013). In a recent paper binding sites of VDR and mothers against decapentaplegic homolog 3 (SMAD3) were investigated in hepatic stellar cells. These transforming growth factor $\beta 1$ (TGF $\beta 1$ )-activated cells play an important role in liver fibrosis. In this study it is shown that VDR and SMAD3 can at least transiently co-occupy the same genomic sites and function as enhancers of pro-fibrotic gene expression. However, when calcipotriol [7] is added, the TGF $\beta 1$-induced recruitment of SMAD3 is compromised and binding of VDR to these genomic sites is enhanced 10-fold meaning that liganded VDR antagonizes SMAD residency on chromatin and thereby suppresses pro-fibrotic gene expression (Ding et al., 2013). This genomic feedback circuit is a previously unknown mechanism of calcipotriol [7].

Micro-array studies in various cancer cell lines such as leukemia, prostate, breast, colorectal, and ovarian cancer show that a variety of gene clusters are influenced by $1,25(\mathrm{OH})_{2} \mathrm{D}_{3}$ and its analogs (reviewed in Kriebitzsch et al., 2009). Cell growth, apoptosis, cellular adhesion and extracellular matrix composition, oxidative stress, immune function, intra- and intercellular signaling and steroid/lipid metabolism are frequently modulated processes in cells by $1,25(\mathrm{OH})_{2} \mathrm{D}_{3}$ and its analogs. However, when different cell lines are compared, few $1,25(\mathrm{OH})_{2} \mathrm{D}_{3}$ /analogregulated genes overlap, which suggests that $1,25(\mathrm{OH})_{2} \mathrm{D}_{3}$ and its analogs behave in a cell type- and tissue-specific way. Also studies using human T-cells (Baeke et al., 2011), rat ventricular heart tissue (Bae et al., 2011), and bone marrow-derived mouse dendritic cells (Griffin et al., 2004) have researched the impact of $1,25(\mathrm{OH})_{2} \mathrm{D}_{3}$ analogs on gene expression. In these studies genes important for cell growth, cell death and cell signaling are regulated, but also a large set of genes implicated in the migration of T-cells and dendritic cells are influenced. TX527 [15] imprints human T-cells with a migratory signature and targets them to sites of inflammation (Baeke et al., 2011). Paricalcitol [2] treatment of rats with cardiac hypertrophy prevents the progression of cardiac hypertrophy and the development into chronic heart failure. The genomic changes associated with cardiac hypertrophy in the ventricular heart tissue of these rats are, in part, reversed by paricalcitol [2] administration (Bae et al., 2011). Furthermore, other studies investigated if $1,25(\mathrm{OH})_{2} \mathrm{D}_{3}$ analogs are able to bind and regulate different genes compared to $1,25(\mathrm{OH})_{2} \mathrm{D}_{3}$. All conducted studies conclude that $1,25(\mathrm{OH})_{2} \mathrm{D}_{3}$ and its analogs induce or repress the same set of genes. Seocalcitol [10] induces a less malignant phenotype in SCC25 squamous cell carcinoma cells and modulates expression of genes important in cell cycle progression, cell adhesion, extracellular matrix composition, intraand intercellular signaling, G-protein coupled function, redox balance, and steroid metabolism. In these cells, seocalcitol [10] regulates the same genes compared to $1,25(\mathrm{OH})_{2} \mathrm{D}_{3}$, however gene regulation by $1,25(\mathrm{OH})_{2} \mathrm{D}_{3}$ is more transient (Lin et al., 2002). Also WY1112, a seco-9,11-bisnor-17-methyl analog lacking the C-ring and with a 21-epi side chain which is fluorinated on C26 and C27 [17], was investigated in MCF-7 breast cancer cells. Despite the 400-fold stronger antiproliferative capacity of WY1112 [17], the same genes are upregulated after $1,25(\mathrm{OH})_{2} \mathrm{D}_{3}$ or WY1112 [17] treatment. However, the induction ability is much higher for the analog (Vanoirbeek et al., 2009). When treating human coronary artery smooth muscle cells with equal amounts of $1,25(\mathrm{OH})_{2} \mathrm{D}_{3}$ or paricalcitol [2] the same genes are regulated (Wu-Wong et al., 2007; Shalhoub et al., 2010). In conclusion, differences in action and capacity of vitamin D analogs are more due to their specific sensitivities to metabolism and their specific interaction with the VDR, co-activators and VDREs than from different gene regulations. However, to our knowledge no studies have yet looked into the potential differences elicited by analogs compared to $1,25(\mathrm{OH})_{2} \mathrm{D}_{3}$ in the fields of proteomics and epigenetics, which could help to understand the molecular mechanism of $1,25(\mathrm{OH})_{2} \mathrm{D}_{3}$ and its analogs on different cell and tissue types.

\section{EFFECTS OF VITAMIN D ANALOGS IN CANCER}

The use of $1,25(\mathrm{OH})_{2} \mathrm{D}_{3}$ for the treatment of cancer gained interest since many tissues express vitamin $\mathrm{D}$ metabolizing enzymes as well as the VDR and because $1,25(\mathrm{OH})_{2} \mathrm{D}_{3}$ has potent antiproliferative and prodifferentiating effects on normal and malignant cell lines. Several analogs evaluated in vitro show stronger antiproliferative and prodifferentiating effects compared to the mother compound in different cancer cell lines. These compounds are further evaluated in rodent models to assess their anti-cancer activity and safety in vivo. All in vivo studies using rodent cancer models that were published between 2007 and 2013 are summarized in Table 3. For studies preceding 2007, the reader is referred to other reviews (Eelen et al., 2007). In most studies the growth of the tumor is inhibited without inducing severe hypercalcemia when appropriate doses of vitamin D analogs are used (Abe et al., 1991; Kawa et al., 1996, 2005; Akhter et al., 1997, Blutt et al., 2000; Prudencio et al., 2001; Grostern et al., 2002; Flanagan et al., 2003; Albert et al., 2004a; Wietrzyk et al., 2004; Zhang et al., 2005; Fichera et al., 2007; van Ginkel et al., 2007; Ghous et al., 2008; Lee et al., 2008; Schwartz et al., 2008; GonzalezPardo et al., 2010; Seubwai et al., 2010; Berkovich et al., 2013; 
Table 3 | In vivo studies in rodent cancer models treated with vitamin D analogs (intraperitoneal i.p.; subcutaneous s.c.) published between 2007 and 2013.

\begin{tabular}{|c|c|c|c|c|}
\hline Cancer type & Dosage vitamin D analog & Duration of treatment & Outcome & References \\
\hline $\begin{array}{l}\text { Chemically-induced } \\
\text { breast cancer }\end{array}$ & $7 \mu \mathrm{g} / \mathrm{kg} /$ week & Approximately 80 days & $\begin{array}{l}\text { Decreased tumor burden and } \\
\text { volume }\end{array}$ & Liska et al., 2012 \\
\hline $\begin{array}{l}\text { Chemically-induced } \\
\text { breast cancer }\end{array}$ & Oral, $7 \mu \mathrm{g} / \mathrm{kg} /$ week & 116 or 156 days & $\begin{array}{l}\text { Prolonged latency of } \\
\text { mammary gland tumors }\end{array}$ & Macejova et al., 2011 \\
\hline $\begin{array}{l}\text { Hepatocellular carcinoma } \\
\text { xenograft }\end{array}$ & $\begin{array}{l}\text { Oral and i.p., } \\
0.02 / 0.1 / 0.5 \mu \mathrm{g} / \mathrm{kg} / \mathrm{d}\end{array}$ & Approximately 21 days & Inhibition of tumor growth & Ghous et al., 2008 \\
\hline $\begin{array}{l}\text { Inoculation with mice } \\
\text { breast cancer cells }\end{array}$ & i.p., $20 \mathrm{ng} 3 \times /$ week & 6 weeks & $\begin{array}{l}\text { Inhibition of tumor growth, no } \\
\text { inhibition of tumor } \\
\text { angiogenesis }\end{array}$ & Valrance et al., 2007 \\
\hline
\end{tabular}

HY-11 (2-amino-3-deoxy-19-nor-22-ene-26-dihomo-27-dihomo-25(OH) $\mathrm{D}_{3}$ )<smiles>CCC(C)(CC)C/C=C\[C@H](C)[C@H]1CC[C@H]2/C(=C/C=C3CCNCC3)CCC[C@@]21C</smiles>

Inoculation with mice

i.p., $10^{-5} \mathrm{M} / \mathrm{d}$

26 days

$50 \%$ increase in survival

Yoon et al., 2008

leukemia cells<smiles>C=C1/C(=C\C=C2/CCC[C@@]3(C)C(C(C)CC[C@H](O)C(C)C)CC[C@H]23)C[C@@H](O)C[C@H]1O</smiles>

\begin{tabular}{llll}
\hline $\begin{array}{l}\text { Inoculation with mice } \\
\text { colorectal cancer cells }\end{array}$ & $\begin{array}{l}\text { Different concentrations s.c. } \\
(3 \text { or } 5 \times / \text { week }) \text { or oral } \\
(3 \times / \text { week }) \text { in combination } \\
\text { with different concentrations } \\
\text { of 5-fluorouracil }\end{array}$ & Variable duration & $\begin{array}{l}1 \mu \mathrm{g} / \mathrm{kg} / \mathrm{d} \text { optimal dose }+ \\
\text { prolongation of life span of } \\
\text { mice (synergistic effect when } \\
\text { combined with } \\
\text { chemotherapy) }\end{array}$ \\
\hline $\begin{array}{l}\text { Inoculation with mice or } \\
\text { human colorectal cancer } \\
\text { cells }\end{array}$ & $\begin{array}{l}\text { S.c., Different concentrations } \\
\text { in combination with different } \\
\text { concentraties of irinotecan or } \\
\text { oxaliplatin }\end{array}$ & Variable duration & $\begin{array}{l}\text { Under certain experimental } \\
\text { conditions vitamin D analogs } \\
\text { and chemotherapy can work } \\
\text { synergistically }\end{array}$
\end{tabular}


Table 3 | Continued

\begin{tabular}{|c|c|c|c|c|}
\hline Cancer type & Dosage vitamin D analog & Duration of treatment & Outcome & References \\
\hline $\begin{array}{l}\text { Squamous cell carcinoma } \\
\text { xenograft }\end{array}$ & i.p., 80/160/320 $\mu \mathrm{g} / \mathrm{mouse} / \mathrm{d}$ & 3 days & $\begin{array}{l}\text { Inhibition of tumor growth, } \\
\text { increased apoptosis, } \\
\text { decreased proliferation }\end{array}$ & Ma et al., 2013 \\
\hline Prostate cancer xenograft & i.p., $1300 \mu \mathrm{g} / \mathrm{kg} 3 \times /$ week & 42 days & $\begin{array}{l}\text { Delay of tumor growth, } 50 \% \\
\text { decrease in tumor weight and } \\
\text { decreased tumor vascularity }\end{array}$ & Okamoto et al., 2012 \\
\hline $\begin{array}{l}\text { Kaposi sarcoma } \\
\text { xenograft }\end{array}$ & i.p., $10 \mu \mathrm{g} / \mathrm{kg} / \mathrm{d}$ & 4 days & Decreased tumor progression & $\begin{array}{l}\text { Gonzalez-Pardo et al., } \\
2010\end{array}$ \\
\hline
\end{tabular}

\section{Paricalcitol (19-nor-1 $\left.\alpha, 25(\mathrm{OH})_{2} \mathrm{D}_{2}\right)$}<smiles>CC(/C=C/C(C)C(C)(C)O)C1CCC2/C(=C/C=C3CC(O)CC(O)C3)CCCC21C</smiles>

\begin{tabular}{llll}
\hline Gastric cancer xenograft & S.c., $100 \mathrm{ng} / \mathrm{d} 3 \times /$ week & 4 weeks & $\begin{array}{l}\text { Lower tumor volume, } \\
\text { reduced growth of } \\
\text { intraperitoneal metastasis }\end{array}$ \\
\hline $\begin{array}{l}\text { Pancreatic cancer } \\
\text { xenograft }\end{array}$ & S.c., $2.5 \mu \mathrm{g} / \mathrm{kg} 3 \times /$ week & Variable duration & Inhibition of tumor growth
\end{tabular}

\begin{tabular}{lll} 
Neuroblastoma xenograft Oral, $0.15 / 0.3 \mu \mathrm{g} / \mathrm{d}$ & Lower tumor volume \\
\hline & &
\end{tabular}


Table 3 | Continued

\begin{tabular}{|c|c|c|c|c|}
\hline Cancer type & Dosage vitamin D analog & Duration of treatment & Outcome & References \\
\hline $\begin{array}{l}\text { Cholangiocarcinoma } \\
\text { xenograft }\end{array}$ & i.p., $15 \mu \mathrm{g} / \mathrm{kg} / \mathrm{d}$ & 17 days & Inhibition of tumor growth & Seubwai et al., 2010 \\
\hline \multicolumn{5}{|c|}{ Calcipotriol (22-ene-26,27-dehydro-1 $\alpha, 25(\mathrm{OH})_{2} \mathrm{D}_{3}$ ) } \\
\hline $\begin{array}{l}\text { UV-induced } \\
\text { non-melanoma skin } \\
\text { cancer }\end{array}$ & $\begin{array}{l}\text { Topical application in } \\
\text { combination with diclofenac } \\
\text { and difluoromethylornithine }\end{array}$ & 17 weeks & $\begin{array}{l}\text { Decrease in number and area } \\
\text { of tumors when combined } \\
\text { with diclofenac }\end{array}$ & Pommergaard et al., 2013 \\
\hline
\end{tabular}

BGP-13 (1R, 3S, 5Z)-5-((8E)-2-((3R)-3-((2R, 3S)-3-(5-cyclopropyl-3H-1,2-dioxol-3-yl)-2-ethyl-3-methylcyclohexylidene) ethylidene)-4-methylenecyclohexane-1,3-diol)

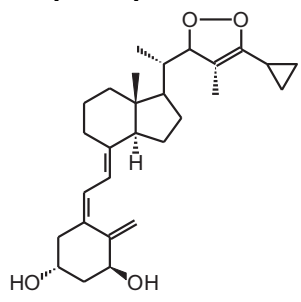

Colorectal cancer i.p., $2 \mu \mathrm{g} / \mathrm{kg}$ every 2 days $\quad 8$ days Inhibition of tumor growth Berkovich et al., 2013
xenograft

PRI-2205 ((5E,7E)-22-ene-26,27-dehydro-1 $\left.\alpha, 25(\mathrm{OH})_{2} \mathrm{D}_{3}\right)$<smiles>C=C1/C(=C/C=C2\CCCC3CCC2C3(C)/C=C/C(O)C2CC2)CC(O)CC1O</smiles>

Breast and lung cancer xenograft s.c., $10 \mu \mathrm{g} / \mathrm{kg} 2$ or $3 \times /$ week $+\quad 18-21$ days cytostatics
Combination of analogs with

Wietrzyk et al., 2007 low doses of cytostatics is not effective 
Table 3 | Continued

Cancer type Dosage vitamin D analog Duration of treatment

\begin{tabular}{|c|c|c|c|c|}
\hline $\begin{array}{l}\text { Inoculation with mice } \\
\text { breast cancer cells }\end{array}$ & s.c., 0.1 or $1 \mu \mathrm{g} / \mathrm{kg} / \mathrm{d}$ & 9 or 11 days & No effects & Wietrzyk et al., 2008 \\
\hline
\end{tabular}

BXL-01-0126 (20R-(4-hydroxy-4-methylpentyl)-23-yne-26,27-hexafluoro-19-nor-1 $\alpha, 25(\mathrm{OH})_{2} \mathrm{D}_{3}$ )<smiles>CC(C)(O)CCCC1CCCC(=CC=C2CC(O)CC(O)C2)C2CCC1C2CCC(C)(C)O</smiles>

\begin{tabular}{|c|c|c|c|c|}
\hline $\begin{array}{l}\text { Acute myeloid leukemia } \\
\text { xenograft }\end{array}$ & i.p., $0.0625 \mu \mathrm{g}$ & 1 injection & $\begin{array}{l}\text { Cathelicidin antimicrobial } \\
\text { peptide present in systemic } \\
\text { circulation }\end{array}$ & Okamoto et al., 2014 \\
\hline
\end{tabular}

BXL0124 (20R-21(3-hydroxy-3-deuteromethyl-4,4,4-trideuterobutyl)-23-yne-26,27-hexafluoro-1 $\left.\alpha, 25(\mathrm{OH})_{2} \mathrm{D}_{3}\right)$

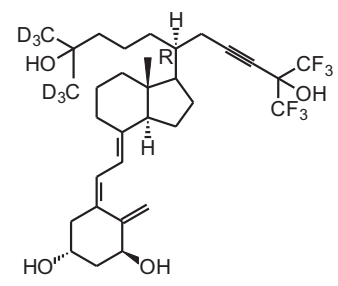

\begin{tabular}{|c|c|c|c|c|}
\hline Breast cancer xenograft & $\begin{array}{l}\text { i.p., } 0.1 \mu \mathrm{g} / \mathrm{kg} \text { or oral } \\
0.03 / 0.1 \mu \mathrm{g} / \mathrm{kg} 6 \text { days } / \text { week }\end{array}$ & 5 weeks & Suppressed tumor growth & So et al., 2011 \\
\hline $\begin{array}{l}\text { Transgenic mice with } \\
\text { breast cancer } \\
\text { (ErbB2/Her-2/neu }\end{array}$ & i.p., $0.3 \mu \mathrm{g} / \mathrm{kg} 3 \times /$ week & Approximately 38 weeks & $\begin{array}{l}\text { Inhibition of tumor growth } \\
\text { and regulation of } \\
\text { ErbB2/AKT/ERK pathway }\end{array}$ & Lee et al., 2010 \\
\hline
\end{tabular}

Gemini0097 (20R-21(3-trideuteromethyl-3-hydroxy-4,4,4-trideuterobutyl)-23-yne-26,27-hexafluoro-19-nor-1 $\left.\alpha, 25(\mathrm{OH})_{2} \mathrm{D}_{3}\right)$

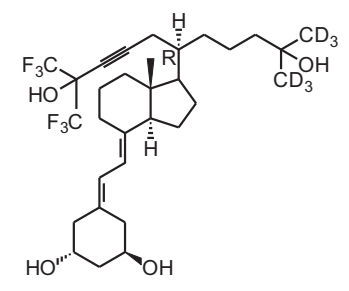

\begin{tabular}{llll}
\hline $\begin{array}{l}\text { ER-negative breast } \\
\text { cancer xenograft }\end{array}$ & i.p., $0.1 \mu \mathrm{g} / \mathrm{kg} / \mathrm{d}$ & 9 weeks & Suppressed tumor growth \\
$\begin{array}{l}\text { Chemically-induced } \\
\text { breast cancer (ER }\end{array}$ & $\begin{array}{l}\text { i.p., } 0.03 / 0.1 / 0.3 \mu \mathrm{g} / \mathrm{kg} \\
\text { 5days } / \text { week }\end{array}$ & 9 weeks & Inhibition of tumor burden \\
posive, 2008
\end{tabular}

positive) 
but here the results are more conflicting. Some studies show no effect of vitamin D analogs on angiogenesis (Oades et al., 2002; Valrance et al., 2007), while others find decreased angiogenesis of xenograft tumors. Intraperitoneal injections of inecalcitol [14] decrease the vascularity of xenografted prostate cancer cells (Okamoto et al., 2012) and oral treatment of colorectal tumors in rats with alfacalcidol [8] also inhibits tumor angiogenesis (Iseki et al., 1999). All in vivo studies conclude that vitamin D analogs inhibit tumor growth but vitamin D and its analogs often do not influence tumor number. Seocalcitol [10] was given as chemoprevention in a transgenic mouse model for androgen-independent prostate cancer. Tumor growth is inhibited, however, there is no prevention in the development of tumors (Perez-Stable et al., 2002).

Since vitamin D and its analogs do not possess cytostatic properties, many in vivo studies have focused on vitamin $\mathrm{D}$ analog cancer treatment combined with radiotherapy and/or chemotherapy. When seocalcitol [10] is combined with radiotherapy in a xenograft model for breast cancer, the anti-cancer effects are more effective compared to monotherapy (Sundaram et al., 2003). Another analog, tacalcitol [6], has been investigated in colorectal cancer xenograft in combination with different standard chemotherapies. Different concentrations as well as administration routes of tacalcitol [6] or PRI-2205 (an analog of calcipotriol) [18] were used in combination with different concentrations of 5fluorouracil (5-FU). Using specific analog doses and chemotherapy schedules, a synergistic effect on the prolongation of the life span of the mice is achieved (Milczarek et al., 2013a). Also the combination with irinotecan or oxaliplatin was investigated. In this study the mice also show a longer life span and a stronger tumor growth inhibition compared to monotherapy when certain doses of tacalcitol [6] and chemotherapy were used. However, some combinations were more toxic than the monotherapies (Milczarek et al., 2013b). Other studies report better effects when combining calcipotriol [7] and diclofenac in a non-melanoma skin cancer model (Pommergaard et al., 2013). However, the combination of vitamin D analogs with chemotherapy does not always result in additive or synergistic effects. Combining maxacalcitol [5] and 5-FU did not enhance anti-tumor effects in a chemically induced breast cancer model (Iino et al., 1992). Another study investigated calcipotriol [7] and its derivatives in breast and lung cancer in vivo models and concluded that these analogs and low dose cytostatics are not effective in the used models (Wietrzyk et al., 2007). Also tacalcitol [6] in combination with cyclophosphamide does not lead to a significant difference in tumor growth inhibition compared to the vehicle treatment (Wietrzyk et al., 2008).

In view of the promising results that certain vitamin $D$ analogs show against cancer in vitro and in vivo animal models, some analogs have been tested in cancer patients (Table 4). Seocalcitol [10] is an analog that has been extensively studied in vitro and in vivo in different cancer models, however in clinical trials the results are rather disappointing. Patients with advanced breast or colon cancer were treated with different doses of seocalcitol [10] (most patients tolerate $7 \mu \mathrm{g} / \mathrm{d}$ ) but none of them showed a complete or partial response (Gulliford et al., 1998). Also oral seocalcitol [10] treatment in patients with inoperable pancreatic cancer exhibited no objective anti-tumor activity (Evans et al., 2002). Two out of 33 patients with inoperable hepatocellular carcinoma showed a complete response after oral seocalcitol [10] treatment, however the majority of the patients presented stable or progressive disease (Dalhoff et al., 2003). Inecalcitol [14] is in an early stage II of its clinical trial in chronic lymphocytic leukemia. Fifteen patients received $2 \mathrm{mg} / \mathrm{d}$ orally and one patient had a $90 \%$ decrease in blood lymphocyte count after 10 months of treatment, in 8 other patients blood lymphocyte count stopped growing when the treatment started (Hybrigenics, 2014). Intravenous administration of paricalcitol [2], an analog that is approved for secondary hyperparathyroidism, also displayed no objective responses in patients with androgen-independent prostate cancer. However, elevated serum PTH levels, which are common for advanced prostate cancers, are reduced by the analog (Schwartz et al., 2005). Doxercalciferol [3], also used in the treatment against secondary hyperparathyroidism, was investigated in androgen-independent prostate cancer patients. A phase I study administered oral doxercalciferol [3] between 5 and $15 \mu \mathrm{g} / \mathrm{d}$, which was well tolerated by the patients (Liu et al., 2002). In the following phase II study, patients were treated with $12.5 \mu \mathrm{g} / \mathrm{d}$ for a minimum of 8 weeks and $30 \%$ of these patients experienced stable disease for over 6 months (Liu et al., 2003). Oral treatment of non-Hodgkin's lymphoma patients with $1 \mu \mathrm{g} / \mathrm{d}$ alfacalcidol [8], a pre-metabolite of $1,25(\mathrm{OH})_{2} \mathrm{D}_{3}$, resulted in a low overall response. Out of 34 treated patients, only 4 had a complete response and 4 others showed a partial response to the treatment (Raina et al., 1991). Calcipotriol [7] is often used to treat skin psoriasis and has thus been investigated in patients with locally advanced or cutaneous metastases from breast cancer. In both studies the analog was applied topically at a dose of $100 \mu \mathrm{g} / \mathrm{d}$. One study reported no response after 3 months of treatment (O'Brien et al., 1993), while in the other study 3 patients showed a $50 \%$ reduction in the diameter of treated lesions after 6 weeks (Bower et al., 1991). A more recently developed analog, ILX23-7553 [19], was investigated in 16 patients with advanced solid tumors but no objective response was seen (Jain et al., 2011). Similar to the in vivo studies, clinical trials have also combined vitamin $\mathrm{D}$ analogs with standard radiotherapy or chemotherapy. Metastatic breast cancer patients were given oral paricalcitol [2] doses between 2 and $7 \mu \mathrm{g} / \mathrm{d}$ in combination with taxane-based chemotherapy and this regimen was well tolerated by the patients (Lawrence et al., 2013). Oral inecalcitol [14] was given to patients with hormone-refractory prostate cancer in combination with docetaxel for maximum 18 weeks. This study had a response rate of $85 \%$ based on a PSA decline of at least 30\% within 3 months of treatment (Hybrigenics, 2014). In a small study with acute non-lymphoid leukemia patients the combination of alfacalcidol [8] and chemotherapy resulted in $17 \%$ of the patients with a complete response and $45 \%$ with a partial response (Petrini et al., 1991). The same analog was combined with standard treatment of surgery, radiotherapy, and/or chemotherapy in glioblastoma and anaplastic astrocytomas. Here, $0.04 \mu \mathrm{g} / \mathrm{kg} / \mathrm{d}$ alfacalcidol [8] was administered resulting in $27 \%$ of the patients with progressive regression of the lesion and complete clinical remission (Trouillas et al., 2001). In metastatic renal cell carcinoma patients, oral treatment of $1 \mu \mathrm{g}$ alfacalcidol/d [8] 
Table 4 | Clinical trials with vitamin D analog supplementation.

\begin{tabular}{|c|c|c|c|c|c|}
\hline Cancer type & $\begin{array}{l}\text { Sample } \\
\text { size }\end{array}$ & $\begin{array}{l}\text { Dosage vitamin D } \\
\text { analog }\end{array}$ & $\begin{array}{l}\text { Duration of } \\
\text { treatment }\end{array}$ & Outcome & References \\
\hline \multicolumn{6}{|c|}{ Seocalcitol (22,24-diene-24,26,27-trishomo-1 $\left.\alpha, 25(\mathrm{OH})_{2} \mathrm{D}_{3}\right)$} \\
\hline $\begin{array}{l}\text { Inoperable } \\
\text { hepatocellular } \\
\text { carcinoma }\end{array}$ & 33 & $\begin{array}{l}\text { Oral individual dosage, } \\
\text { most patients tolerate } \\
10 \mu \mathrm{g} / \mathrm{d}\end{array}$ & Up to 1 year & $\begin{array}{l}2 \text { patients with complete response; } \\
12 \text { with stable disease; } 19 \text { with } \\
\text { progressive disease }\end{array}$ & $\begin{array}{l}\text { Dalhoff et al., } 2003 \\
\text { (uncontrolled trial) }\end{array}$ \\
\hline $\begin{array}{l}\text { Advanced breast } \\
\text { cancer and colorectal } \\
\text { cancer }\end{array}$ & 36 & $\begin{array}{l}\text { Individual dosage } \\
\text { (solution), most patients } \\
\text { tolerate } 7 \mu \mathrm{g} / \mathrm{d}\end{array}$ & $\begin{array}{l}\text { From } 5 \text { days up to } 1 \\
\text { year }\end{array}$ & No complete or partial responses & $\begin{array}{l}\text { Gulliford et al., } 1998 \\
\text { (uncontrolled trial) }\end{array}$ \\
\hline
\end{tabular}

Inecalcitol (19-nor-14-epi-23-yne-1 $\alpha, 25(\mathrm{OH})_{2} \mathrm{D}_{3}$ )<smiles>CC(C)C1CCC2/C(=C/C=C3C[C@@H](O)C[C@H](O)C3)CCCC21C</smiles>

\begin{tabular}{|c|c|c|c|c|c|}
\hline $\begin{array}{l}\text { Hormone-refractory } \\
\text { prostate cancer }\end{array}$ & 54 & $\begin{array}{l}\text { Oral individual dosage, } \\
\text { maximum tolerated dose } \\
\text { is } 4 \mathrm{mg} / \mathrm{d}+\text { docetaxel } \\
\text { (chemotherapy) }\end{array}$ & Maximum 18 weeks & $\begin{array}{l}85 \% \text { response rate based on a PSA } \\
\text { decline of at least } 30 \% \text { within } 3 \\
\text { months }\end{array}$ & $\begin{array}{l}\text { Hybrigenics, } 2014 \\
\text { (uncontrolled trial) }\end{array}$ \\
\hline $\begin{array}{l}\text { Chronic lymphocytic } \\
\text { leukemia }\end{array}$ & 15 & Oral $2 \mathrm{mg} / \mathrm{d}$ & Not found & $\begin{array}{l}1 \text { patient had a } 90 \% \text { decrease in blood } \\
\text { lymphocyte count after } 10 \text { months of } \\
\text { treatment; in } 8 \text { patients blood } \\
\text { lymphocyte count stopped increasing } \\
\text { when treatment was started; } 6 \\
\text { patients showed no response }\end{array}$ & $\begin{array}{l}\text { Hybrigenics, } 2014 \\
\text { (uncontrolled trial) }\end{array}$ \\
\hline
\end{tabular}

\section{Paricalcitol (19-nor-1 $\left.\alpha, 25(\mathrm{OH})_{2} \mathrm{D}_{2}\right)$}

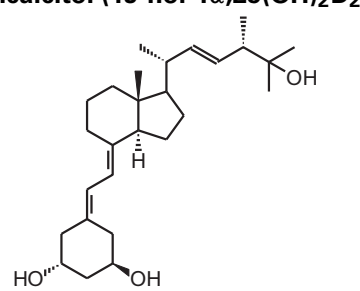

\begin{tabular}{lllll}
\hline $\begin{array}{l}\text { Metastatic breast } \\
\text { cancer }\end{array}$ & Oral individual dosage, & 8 weeks & Well tolerated regimen & Lawrence et al., 2013 \\
& $2-7 \mu \mathrm{g} / \mathrm{d}+$ taxane-based \\
chemotherapy & &
\end{tabular}


Table 4 | Continued

\begin{tabular}{|c|c|c|c|c|c|}
\hline Cancer type & $\begin{array}{l}\text { Sample } \\
\text { size }\end{array}$ & $\begin{array}{l}\text { Dosage vitamin D } \\
\text { analog }\end{array}$ & $\begin{array}{l}\text { Duration of } \\
\text { treatment }\end{array}$ & Outcome & References \\
\hline $\begin{array}{l}\text { Androgen- } \\
\text { independent } \\
\text { prostate cancer }\end{array}$ & 18 & $\begin{array}{l}\text { i.v., Individual dosage, } \\
3 \times / \text { week } 5-25 \mu \mathrm{g}\end{array}$ & Up to 12 weeks & $\begin{array}{l}\text { No objective response, reduced } \\
\text { serum PTH levels }\end{array}$ & $\begin{array}{l}\text { Schwartz et al., } 2005 \\
\text { (uncontrolled) }\end{array}$ \\
\hline
\end{tabular}

\begin{tabular}{|c|c|c|c|c|c|}
\hline \multicolumn{6}{|c|}{ Doxercalciferol $\left(1 \alpha(\mathrm{OH}) \mathrm{D}_{2}\right)$} \\
\hline $\begin{array}{l}\text { Localized prostate } \\
\text { cancer and high } \\
\text { grade prostatic } \\
\text { intraepithelial } \\
\text { neoplasia }\end{array}$ & 31 & Oral, $10 \mu \mathrm{g} / \mathrm{d}$ & 4 weeks & $\begin{array}{l}\text { No beneficial effects in serum and } \\
\text { tissue markers }\end{array}$ & $\begin{array}{l}\text { Gee et al., } 2013 \\
\text { (placebo-controlled) }\end{array}$ \\
\hline $\begin{array}{l}\text { Metastatic } \\
\text { androgen- } \\
\text { independent } \\
\text { prostate cancer }\end{array}$ & 70 & Oral, $10 \mu \mathrm{g} / \mathrm{d}+$ docetaxel & 4 weeks & $\begin{array}{l}\text { No enhanced PSA response rate or } \\
\text { survival }\end{array}$ & $\begin{array}{l}\text { Attia et al., } 2008 \\
\text { (placebo-controlled) }\end{array}$ \\
\hline $\begin{array}{l}\text { Advanced androgen- } \\
\text { independent } \\
\text { prostate cancer }\end{array}$ & 26 & Oral, $12.5 \mu \mathrm{g} / \mathrm{d}$ & Minimum 8 weeks & $\begin{array}{l}30 \% \text { experienced stable disease for } \\
\text { over } 6 \text { months }\end{array}$ & $\begin{array}{l}\text { Liu et al., } 2003 \\
\text { (uncontrolled) }\end{array}$ \\
\hline $\begin{array}{l}\text { Advanced androgen- } \\
\text { independent } \\
\text { prostate cancer }\end{array}$ & 25 & $\begin{array}{l}\text { Oral individual dosage, } \\
5-15 \mu \mathrm{g} / \mathrm{d}\end{array}$ & Minimum 8 weeks & $\begin{array}{l}\text { Well tolerated, maximal tolerated } \\
\text { dose was not reached }\end{array}$ & $\begin{array}{l}\text { Liu et al., } 2002 \\
\text { (uncontrolled) }\end{array}$ \\
\hline
\end{tabular}

\begin{tabular}{|c|c|c|c|c|c|}
\hline \multicolumn{6}{|c|}{ Alfacalcidol $\left(1 \alpha(\mathrm{OH}) \mathrm{D}_{3}\right)$} \\
\hline $\begin{array}{l}\text { Metastatic renal cell } \\
\text { carcinoma }\end{array}$ & 16 & $\begin{array}{l}\text { Oral, } 1 \mu \mathrm{g} / \mathrm{d}+ \\
\text { interferon- } \alpha(3 \times / \text { week })\end{array}$ & Minimum 3 months & $25 \%$ had partial response & $\begin{array}{l}\text { Obara et al., } 2008 \\
\text { (uncontrolled) }\end{array}$ \\
\hline $\begin{array}{l}\text { Glioblastoma and } \\
\text { anaplastic } \\
\text { astrocytomas }\end{array}$ & 11 & $\begin{array}{l}0.04 \mu \mathrm{g} / \mathrm{kg} / \mathrm{d}+ \\
\text { surgery/chemotherapy/ } \\
\text { radiotherapy }\end{array}$ & Not found & $\begin{array}{l}27 \% \text { showed progressive regression } \\
\text { of the lesion and had a complete } \\
\text { clinical remission }\end{array}$ & $\begin{array}{l}\text { Trouillas et al., } 2001 \\
\text { (uncontrolled) }\end{array}$ \\
\hline $\begin{array}{l}\text { Myelodysplastic } \\
\text { syndromes }\end{array}$ & 30 & Oral, 4-6 $\mu \mathrm{g} / \mathrm{d}$ & Median 17 months & $\begin{array}{l}\text { Prolongation of leukemic } \\
\text { transformation-free survival }\end{array}$ & $\begin{array}{l}\text { Motomura et al., } \\
1991 \\
\text { (placebo-controlled) }\end{array}$ \\
\hline $\begin{array}{l}\text { Acute non-lymphoid } \\
\text { leukemia }\end{array}$ & 11 & Analog + chemotherapy & Not found & $\begin{array}{l}17 \% \text { complete remission, } 45 \% \text { partial } \\
\text { remission }\end{array}$ & $\begin{array}{l}\text { Petrini et al., } 1991 \\
\text { (uncontrolled) }\end{array}$ \\
\hline $\begin{array}{l}\text { Progressive } \\
\text { low-grade } \\
\text { non-Hodgkin's } \\
\text { lymphoma }\end{array}$ & 34 & Oral, $1 \mu \mathrm{g} / \mathrm{d}$ & Minimum 8 weeks & $\begin{array}{l}4 \text { patients has a complete response, } 4 \\
\text { other patients had a partial response }\end{array}$ & $\begin{array}{l}\text { Raina et al., } 1991 \\
\text { (uncontrolled) }\end{array}$ \\
\hline
\end{tabular}


Table 4 | Continued

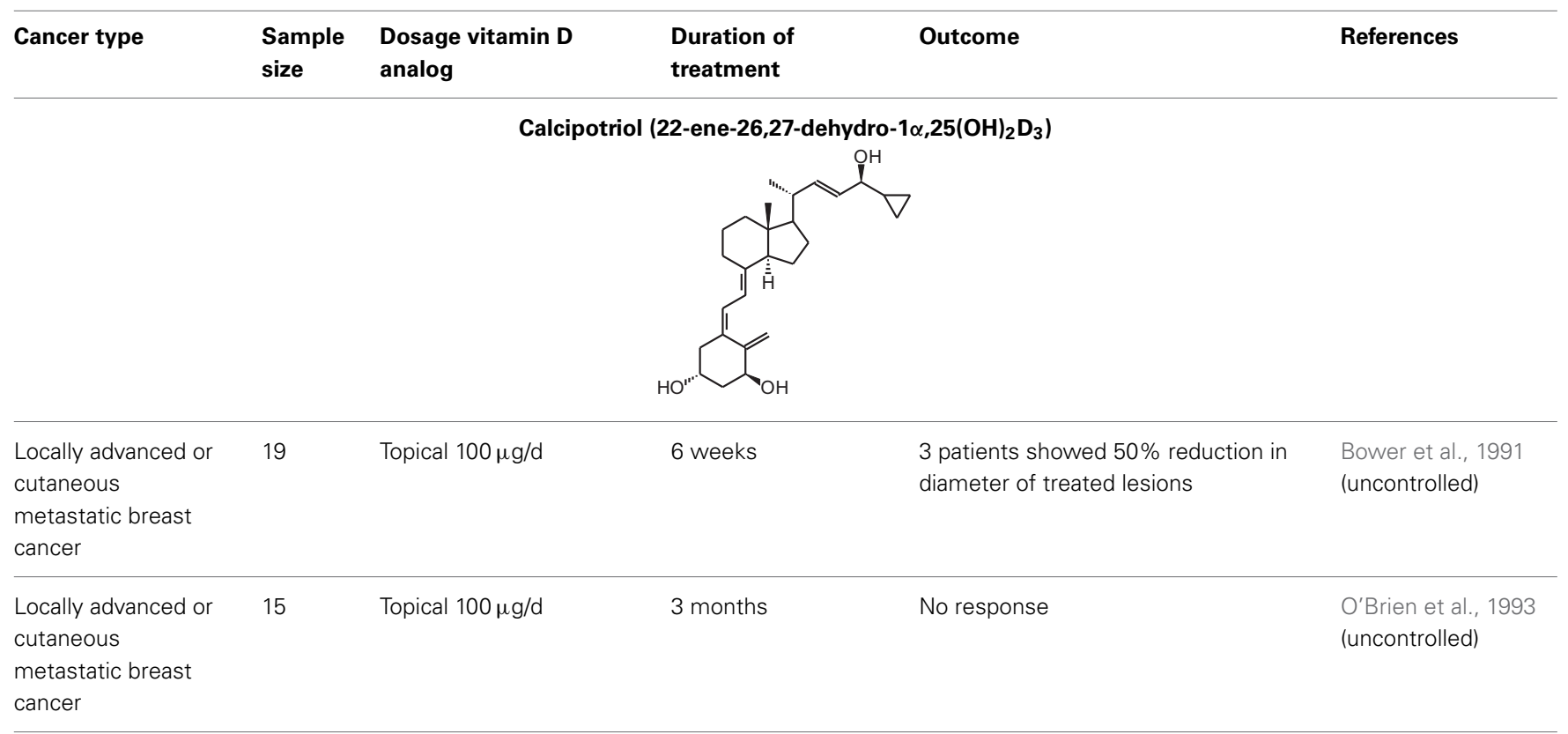

ILX23-7553 (16-ene-23-yne-1 $\alpha, 25(\mathrm{OH})_{2} \mathrm{D}_{3}$ )<smiles>C=C1/C(=C\C=C2/CCCCC2C)CCC1C(C)CC#CC(C)(C)O</smiles>

\begin{tabular}{|c|c|c|c|c|c|}
\hline $\begin{array}{l}\text { Advanced solid } \\
\text { tumors }\end{array}$ & 16 & $\begin{array}{l}\text { Oral individual dosage, } \\
1.7-37.3 \mu \mathrm{g} / \mathrm{m}^{2} / \mathrm{d} \text { for } 3 \\
\text { consecutive days, } \\
\text { repeated in 7-day cycle }\end{array}$ & Minimum 3 weeks & No objective response & $\begin{array}{l}\text { Jain et al., } 2011 \\
\text { (uncontrolled) }\end{array}$ \\
\hline
\end{tabular}

was combined with a 3 weekly administration of interferon- $\alpha$ for minimal 3 months. In these patients $25 \%$ had a partial response to the combination therapy (Obara et al., 2008). Randomized, placebo-controlled studies have been conducted with oral doxercalciferol [3] or alfacalcidol [8]. One study administered $10 \mu \mathrm{g} / \mathrm{d}$ doxercalciferol [3] or placebo during 4 weeks to patients with localized prostate cancer or high-grade prostatic intraepithelial neoplasia. However, no beneficial effects in serum or tissue markers were seen (Gee et al., 2013). Another study used the same dose in metastatic androgen-independent prostate cancer patients but combined the treatment with docetaxel. Also here, no enhanced PSA response rate or survival rate was seen after 4 weeks of treatment (Attia et al., 2008). Oral alfacalcidol [8] or placebo was given to patients with myelodysplastic syndromes. In the patients treated with the analog, a prolongation of leukemic transformation-free survival was seen compared to the placebo group (Motomura et al., 1991). Despite the promising in vitro and in vivo results of vitamin $\mathrm{D}$ analogs in cancer models, clinical trials have failed to proof the effects of vitamin D analogs in cancer patients. Vitamin D and its analogs lack cytotoxic activity, so using these analogs in combination with standard therapies such as radio- and chemotherapy is probably more effective than using the analogs as monotherapy. Next to the combination of analogs with standard cancer therapies, it is also possible that these analogs need to be given for a longer period of time or that treatment with analogs has to be started earlier, for example in early stages of disease or even as chemoprevention.

\section{CONCLUSIONS AND PERSPECTIVES}

Vitamin D and its analogs exhibit strong antiproliferative and prodifferentiating effects on different normal and malignant cell types. Several vitamin D analogs have been approved for treating psoriasis, osteoporosis, and secondary hyperparathyroidism and are often used as first or second-line treatment option. Despite promising in vitro as well as in vivo results in various cancer models, vitamin D analog treatment in clinical trials with cancer patients failed to prove efficacy in most trials. Different combinations of analogs and standard cancer therapies should be further explored as well as the correct duration and timing of administration. To unravel the exact working mechanisms of vitamin D analogs more research studies should compare the effects of vitamin $\mathrm{D}$ analogs in different cell types to the mother compound. 
Furthermore, differences between $1,25(\mathrm{OH})_{2} \mathrm{D}_{3}$ and its analogs are probably more due to their differences in metabolism and coactivator recruitment than from different genetic regulations. However, some fields such as epigenetics and proteomics remain largely unexplored in comparing the potentially distinctive effects of $1,25(\mathrm{OH})_{2} \mathrm{D}_{3}$ and its analogs. Since all current genomic and transcriptomic studies focus on established human cell lines, micro-array, and ChIP techniques comparing the effects of $1,25(\mathrm{OH})_{2} \mathrm{D}_{3}$ and its analogs on human primary tumor tissues should be investigated in the future.

\section{ACKNOWLEDGMENTS}

This work was supported by grants from the Fund for Scientific Research (G.0587.09; G.0A17.14N) and the KU Leuven (GOA/14/010).

\section{REFERENCES}

Abe, J., Nakano, T., Nishii, Y., Matsumoto, T., Ogata, E., and Ikeda, K. (1991). A novel vitamin D3 analog, 22-oxa-1,25-dihydroxyvitamin D3, inhibits the growth of human breast cancer in vitro and in vivo without causing hypercalcemia. Endocrinology 129, 832-837. doi: 10.1210/endo-129-2-832

Akhter, J., Chen, X., Bowrey, P., Bolton, E. J., and Morris, D. L. (1997). Vitamin D3 analog, EB1089, inhibits growth of subcutaneous xenografts of the human colon cancer cell line, LoVo, in a nude mouse model. Dis. Colon Rectum 40, 317-321. doi: 10.1007/BF02050422

Albert, D. M., Kumar, A., Strugnell, S. A., Darjatmoko, S. R., Lokken, J. M., Lindstrom, M. J., et al. (2004a). Effectiveness of 1alpha-hydroxyvitamin D2 in inhibiting tumor growth in a murine transgenic pigmented ocular tumor model. Arch. Ophthalmol. 122, 1365-1369. doi: 10.1001/archopht.122.9.1365

Albert, D. M., Kumar, A., Strugnell, S. A., Darjatmoko, S. R., Lokken, J. M., Lindstrom, M. J., et al. (2004b). Effectiveness of vitamin D analogues in treating large tumors and during prolonged use in murine retinoblastoma models. Arch. Ophthalmol. 122, 1357-1362. doi: 10.1001/archopht.122.9.1357

Attia, S., Eickhoff, J., Wilding, G., McNeel, D., Blank, J., Ahuja, H., et al. (2008). Randomized, double-blinded phase II evaluation of docetaxel with or without doxercalciferol in patients with metastatic, androgen-independent prostate cancer. Clin. Cancer Res. 14, 2437-2443. doi: 10.1158/1078-0432.CCR07-4274

Bae, S., Yalamarti, B., Ke, Q., Choudhury, S., Yu, H., Karumanchi, S. A., et al. (2011). Preventing progression of cardiac hypertrophy and development of heart failure by paricalcitol therapy in rats. Cardiovasc. Res. 91, 632-639. doi: $10.1093 / \mathrm{cvr} / \mathrm{cvr} 133$

Baeke, F., Korf, H., Overbergh, L., Verstuyf, A., Thorrez, L., Van Lommel, L., et al. (2011). The vitamin D analog, TX527, promotes a human $\mathrm{CD} 4+\mathrm{CD} 25$ highCD127low regulatory $\mathrm{T}$ cell profile and induces a migratory signature specific for homing to sites of inflammation. J. Immunol. 186, 132-142. doi: 10.4049/jimmunol.1000695

Berkovich, L., Sintov, A. C., and Ben-Shabat, S. (2013). Inhibition of cancer growth and induction of apoptosis by BGP-13 and BGP-15, new calcipotriene-derived vitamin D3 analogs, in-vitro and in-vivo studies. Invest. New Drugs 31, 247-255. doi: 10.1007/s10637-012-9839-1

Bhatia, V., Saini, M. K., Shen, X., Bi, L. X., Qiu, S., Weigel, N. L., et al. (2009). EB1089 inhibits the parathyroid hormone-related protein-enhanced bone metastasis and xenograft growth of human prostate cancer cells. Mol. Cancer Ther. 8, 1787-1798. doi: 10.1158/1535-7163.MCT-09-0064

Blutt, S. E., Polek, T. C., Stewart, L. V., Kattan, M. W., and Weigel, N. L. (2000). A calcitriol analogue, EB1089, inhibits the growth of LNCaP tumors in nude mice. Cancer Res. 60, 779-782.

Bower, M., Colston, K. W., Stein, R. C., Hedley, A., Gazet, J. C., Ford, H. T., et al. (1991). Topical calcipotriol treatment in advanced breast cancer. Lancet 337, 701-702. doi: 10.1016/0140-6736(91)90280-3

Chiang, K. C., Yeh, C. N., Hsu, J. T., Yeh, T. S., Jan, Y. Y., Wu, C. T., et al. (2013). Evaluation of the potential therapeutic role of a new generation of vitamin $\mathrm{D}$ analog, MART-10, in human pancreatic cancer cells in vitro and in vivo. Cell Cycle 12, 1316-1325. doi: 10.4161/cc.24445
Coburn, J. W., Maung, H. M., Elangovan, L., Germain, M. J., Lindberg, J. S., Sprague, S. M., et al. (2004). Doxercalciferol safely suppresses PTH levels in patients with secondary hyperparathyroidism associated with chronic kidney disease stages 3 and 4. Am. J. Kidney Dis. 43, 877-890. doi: 10.1053/j.ajkd.2004.01.012

Colston, K., Colston, M. J., and Feldman, D. (1981). 1,25-dihydroxyvitamin D3 and malignant melanoma: the presence of receptors and inhibition of cell growth in culture. Endocrinology 108, 1083-1086. doi: 10.1210/endo-108-3-1083

Coyne, D., Acharya, M., Qiu, P., Abboud, H., Batlle, D., Rosansky, S., et al. (2006). Paricalcitol capsule for the treatment of secondary hyperparathyroidism in stages 3 and 4 CKD. Am. J. Kidney Dis. 47, 263-276. doi: 10.1053/j.ajkd.2005.10.007

Dalhoff, K., Dancey, J., Astrup, L., Skovsgaard, T., Hamberg, K. J., Lofts, F. J., et al. (2003). A phase II study of the vitamin D analogue Seocalcitol in patients with inoperable hepatocellular carcinoma. Br. J. Cancer 89, 252-257. doi: 10.1038/sj.bjc.6601104

Danielsson, C., Nayeri, S., Wiesinger, H., Thieroff-Ekerdt, R., and Carlberg, C. (1996). Potent gene regulatory and antiproliferative activities of 20-methyl analogues of 1,25 dihydroxyvitamin D3. J. Cell. Biochem. 63, 199-206. doi: 10.1002/(SICI)1097-4644(19961101)63:2<199::AID-JCB7>3.0.CO;2-T

Dilworth, F. J., Williams, G. R., Kissmeyer, A. M., Nielsen, J. L., Binderup, E., Calverley, M. J., et al. (1997). The vitamin D analog, KH1060, is rapidly degraded both in vivo and in vitro via several pathways: principal metabolites generated retain significant biological activity. Endocrinology 138, 5485-5496. doi: 10.1210/en.138.12.5485

Ding, N., Yu, R. T., Subramaniam, N., Sherman, M. H., Wilson, C., Rao, R., et al. (2013). A vitamin D receptor/SMAD genomic circuit gates hepatic fibrotic response. Cell 153, 601-613. doi: 10.1016/j.cell.2013.03.028

Eelen, G., Gysemans, C., Verlinden, L., Vanoirbeek, E., De Clercq, P., Van Haver, D., et al. (2007). Mechanism and potential of the growth-inhibitory actions of vitamin D and ana-logs. Curr. Med. Chem. 14, 1893-1910. doi: 10.2174/092986707781058823

Eelen, G., Valle, N., Sato, Y., Rochel, N., Verlinden, L., De Clercq, P., et al. (2008). Superagonistic fluorinated vitamin D3 analogs stabilize helix 12 of the vitamin D receptor. Chem. Biol. 15, 1029-1034. doi: 10.1016/j.chembiol.2008.08.008

Eelen, G., Verlinden, L., Rochel, N., Claessens, F., De Clercq, P., Vandewalle, M., et al. (2005). Superagonistic action of 14-epi-analogs of 1,25-dihydroxyvitamin D explained by vitamin D receptor-coactivator interaction. Mol. Pharmacol. 67, 1566-1573. doi: 10.1124/mol.104.008730

El Abdaimi, K., Dion, N., Papavasiliou, V., Cardinal, P. E., Binderup, L., Goltzman, D., et al. (2000). The vitamin D analogue EB 1089 prevents skeletal metastasis and prolongs survival time in nude mice transplanted with human breast cancer cells. Cancer Res. 60, 4412-4418.

Evans, T. R., Colston, K. W., Lofts, F. J., Cunningham, D., Anthoney, D. A., Gogas, H., et al. (2002). A phase II trial of the vitamin D analogue Seocalcitol (EB1089) in patients with inoperable pancreatic cancer. Br. J. Cancer 86, 680-685. doi: $10.1038 /$ sj.bjc. 6600162

Fichera, A., Little, N., Dougherty, U., Mustafi, R., Cerda, S., Li, Y. C., et al. (2007). A vitamin D analogue inhibits colonic carcinogenesis in the AOM/DSS model. J. Surg. Res. 142, 239-245. doi: 10.1016/j.jss.2007.02.038

Flanagan, L., Packman, K., Juba, B., O’Neill, S., Tenniswood, M., and Welsh, J. (2003). Efficacy of Vitamin D compounds to modulate estrogen receptor negative breast cancer growth and invasion. J. Steroid Biochem. Mol. Biol. 84, 181-192. doi: 10.1016/S0960-0760(03)00028-1

Gee, J., Bailey, H., Kim, K., Kolesar, J., Havighurst, T., Tutsch, K. D., et al. (2013). Phase II open label, multi-center clinical trial of modulation of intermediate endpoint biomarkers by lalpha-hydroxyvitamin D2 in patients with clinically localized prostate cancer and high grade pin. Prostate 73, 970-978. doi: 10.1002/pros. 22644

Ghous, Z., Akhter, J., Pourgholami, M. H., and Morris, D. L. (2008). Inhibition of hepatocellular cancer by EB1089: in vitro and in vive study. Anticancer Res. 28, 3757-3761.

Gonzalez-Pardo, V., Martin, D., Gutkind, J. S., Verstuyf, A., Bouillon, R., de Boland, A. R., et al. (2010). 1 Alpha,25-dihydroxyvitamin D3 and its TX527 analog inhibit the growth of endothelial cells transformed by Kaposi sarcomaassociated herpes virus $G$ protein-coupled receptor in vitro and in vivo. Endocrinology 151, 23-31. doi: 10.1210/en.2009-0650

Griffin, M. D., Xing, N., and Kumar, R. (2004). Gene expression profiles in dendritic cells conditioned by 1alpha,25-dihydroxyvitamin D3 analog. 
J. Steroid Biochem. Mol. Biol. 89-90, 443-448. doi: 10.1016/j.jsbmb.2004. 03.039

Grostern, R. J., Bryar, P. J., Zimbric, M. L., Darjatmoko, S. R., Lissauer, B. J., Lindstrom, M. J., et al. (2002). Toxicity and dose-response studies of lalphahydroxyvitamin D2 in a retinoblastoma xenograft model. Arch. Ophthalmol. 120, 607-612. doi: 10.1001/archopht.120.5.607

Gulliford, T., English, J., Colston, K. W., Menday, P., Moller, S., and Coombes, R. C. (1998). A phase I study of the vitamin D analogue EB 1089 in patients with advanced breast and colorectal cancer. Br. J. Cancer 78, 6-13. doi: 10.1038/bjc. 1998.434

Hagino, H., Takano, T., Fukunaga, M., Shiraki, M., Nakamura, T., and Matsumoto, T. (2013). Eldecalcitol reduces the risk of severe vertebral fractures and improves the health-related quality of life in patients with osteoporosis. J. Bone Miner. Metab. 31, 183-189. doi: 10.1007/s00774-012-0397-6

Hamdy, N. A., Kanis, J. A., Beneton, M. N., Brown, C. B., Juttmann, J. R., Jordans, J. G., et al. (1995). Effect of alfacalcidol on natural course of renal bone disease in mild to moderate renal failure. BMJ 310, 358-363. doi: 10.1136/bmj.310.6976.358

Hansen, C. M., and Maenpaa, P. H. (1997). EB 1089, a novel vitamin D analog with strong antiproliferative and differentiation-inducing effects on target cells. Biochem. Pharmacol. 54, 1173-1179. doi: 10.1016/S0006-2952(97)00181-0

Hara, K., Kusuzaki, K., Takeshita, H., Kuzuhara, A., Tsuji, Y., Ashihara, T., et al. (2001). Oral administration of 1 alpha hydroxyvitamin D3 inhibits tumor growth and metastasis of a murine osteosarcoma model. Anticancer Res. 21, 321-324.

Harada, S., Mizoguchi, T., Kobayashi, Y., Nakamichi, Y., Takeda, S., Sakai, S., et al. (2012). Daily administration of eldecalcitol (ED-71), an active vitamin D analog, increases bone mineral density by suppressing RANKL expression in mouse trabecular bone. J. Bone Miner. Res. 27, 461-473. doi: 10.1002/jbmr.555

Hybrigenics. (2014). Inecalcitol. [Internet] Paris, France: Hybrigenics [cited 2014 29/01]. Available online at: http://www.hybrigenics.com/contents/pharma-1/ inecalcitol- 1

Iino, Y., Yoshida, M., Sugamata, N., Maemura, M., Ohwada, S., Yokoe, T., et al. (1992). 1 alpha-hydroxyvitamin D3, hypercalcemia, and growth suppression of 7,12-dimethylbenz[a] anthracene-induced rat mammary tumors. Breast Cancer Res. Treat. 22, 133-140. doi: 10.1007/BF01833343

Iseki, K., Tatsuta, M., Uehara, H., Iishi, H., Yano, H., Sakai, N., et al. (1999). Inhibition of angiogenesis as a mechanism for inhibition by lalphahydroxyvitamin D3 and 1,25-dihydroxyvitamin D3 of colon carcinogenesis induced by azoxymethane in Wistar rats. Int. J. Cancer 81, 730-733. doi: 10.1002/(SICI)1097-0215(19990531)81:5<730::AID-IJC11>3.0.CO;2-Q

Ito, M., Nakamura, T., Fukunaga, M., Shiraki, M., and Matsumoto, T. (2011). Effect of eldecalcitol, an active vitamin D analog, on hip structure and biomechanical properties: 3D assessment by clinical CT. Bone 49, 328-334. doi: 10.1016/j.bone.2011.05.002

Jain, R. K., Trump, D. L., Egorin, M. J., Fernandez, M., Johnson, C. S., and Ramanathan, R. K. (2011). A phase I study of the vitamin D3 analogue ILX237553 administered orally to patients with advanced solid tumors. Invest. New Drugs 29, 1420-1425. doi: 10.1007/s10637-010-9492-5

James, S. Y., Mercer, E., Brady, M., Binderup, L., and Colston, K. W. (1998). EB1089, a synthetic analogue of vitamin $\mathrm{D}$, induces apoptosis in breast cancer cells in vivo and in vitro. Br. J. Pharmacol. 125, 953-962. doi: 10.1038/sj.bjp.0702103

Jensen, S. S., Madsen, M. W., Lukas, J., Binderup, L., and Bartek, J. (2001). Inhibitory effects of 1alpha,25-dihydroxyvitamin $\mathrm{D}(3)$ on the $\mathrm{G}(1)-\mathrm{S}$ phasecontrolling machinery. Mol. Endocrinol. 15, 1370-1380. doi: 10.1210/mend.15. 8.0673

Jones, G. (1997). “Analog metabolism,” in Vitamin D. 1st Edn., ed D. Feldman (San Diego, CA: Academic Press), 973-994.

Kawa, S., Yoshizawa, K., Nikaido, T., and Kiyosawa, K. (2005). Inhibitory effect of 22-oxa-1,25-dihydroxyvitamin D3, maxacalcitol, on the proliferation of pancreatic cancer cell lines. J. Steroid Biochem. Mol. Biol. 97, 173-177. doi: 10.1016/j.jsbmb.2005.06.021

Kawa, S., Yoshizawa, K., Tokoo, M., Imai, H., Oguchi, H., Kiyosawa, K., et al. (1996). Inhibitory effect of 22-oxa-1,25-dihydroxyvitamin D3 on the proliferation of pancreatic cancer cell lines. Gastroenterology 110, 1605-1613. doi: 10.1053/gast.1996.v110.pm8613068

Kissmeyer, A. M., Binderup, E., Binderup, L., Mork Hansen, C., Andersen, N. R., Makin, H. L., et al. (1997). Metabolism of the vitamin D analog EB 1089: identification of in vivo and in vitro liver metabolites and their biological activities. Biochem. Pharmacol. 53, 1087-1097. doi: 10.1016/S0006-2952(96) 00816-7

Kriebitzsch, C., Verlinden, L., Eelen, G., Tan, B. K., Van Camp, M., Bouillon, R., et al. (2009). The impact of 1,25(OH)2D3 and its structural analogs on gene expression in cancer cells-a microarray approach. Anticancer Res. 29, 3471-3483.

Lambert, J. R., Eddy, V. J., Young, C. D., Persons, K. S., Sarkar, S., Kelly, J. A., et al. (2010). A vitamin D receptor-alkylating derivative of 1alpha,25dihydroxyvitamin D3 inhibits growth of human kidney cancer cells and suppresses tumor growth. Cancer Prev. Res. (Phila.) 3, 1596-1607. doi: 10.1158/1940-6207.CAPR-10-0122

Lawrence, J. A., Akman, S. A., Melin, S. A., Case, L. D., and Schwartz, G. G. (2013). Oral paricalcitol (19-nor-1,25-dihydroxyvitamin D2) in women receiving chemotherapy for metastatic breast cancer: a feasibility trial. Cancer Biol. Ther. 14, 476-480. doi: 10.4161/cbt.24350

Lee, H. J., Paul, S., Atalla, N., Thomas, P. E., Lin, X., Yang, I., et al. (2008). Gemini vitamin $\mathrm{D}$ analogues inhibit estrogen receptor-positive and estrogen receptornegative mammary tumorigenesis without hypercalcemic toxicity. Cancer Prev. Res. (Phila.) 1, 476-484. doi: 10.1158/1940-6207.CAPR-08-0084

Lee, H. J., So, J. Y., DeCastro, A., Smolarek, A., Paul, S., Maehr, H., et al. (2010). Gemini vitamin D analog suppresses ErbB2-positive mammary tumor growth via inhibition of ErbB2/AKT/ERK signaling. J. Steroid Biochem. Mol. Biol. 121, 408-412. doi: 10.1016/j.jsbmb.2010.03.053

Lin, R., Nagai, Y., Sladek, R., Bastien, Y., Ho, J., Petrecca, K., et al. (2002). Expression profiling in squamous carcinoma cells reveals pleiotropic effects of vitamin D3 analog EB1089 signaling on cell proliferation, differentiation, and immune system regulation. Mol. Endocrinol. 16, 1243-1256. doi: 10.1210/mend.16.6.0874

Liska, J., Macejova, D., Ondkova, S., and Brtko, J. (2012). Morphology of 1-methyl1-nitrosourea induced rat mammary tumours after treatment with precursor of phytanic acid or its combination with vitamin D analogue. Endocr. Regul. 46, 21-26. doi: 10.4149/endo_2012_021

Liu, G., Oettel, K., Ripple, G., Staab, M. J., Horvath, D., Alberti, D., et al. (2002). Phase I trial of 1alpha-hydroxyvitamin $\mathrm{d}(2)$ in patients with hormone refractory prostate cancer. Clin. Cancer Res. 8, 2820-2827.

Liu, G., Wilding, G., Staab, M. J., Horvath, D., Miller, K., Dresen, A., et al. (2003). Phase II study of 1alpha-hydroxyvitamin $\mathrm{D}(2)$ in the treatment of advanced androgen-independent prostate cancer. Clin. Cancer Res. 9, 4077-4083.

Liu, Y. Y., Nguyen, C., Ali Gardezi, S. A., Schnirer, I., and Peleg, S. (2001). Differential regulation of heterodimerization by 1alpha,25-dihydroxyvitamin $\mathrm{D}(3)$ and its 20-epi analog. Steroids 66, 203-212. doi: 10.1016/S0039$128 X(00) 00151-3$

Liu, Y. Y., Nguyen, C., and Peleg, S. (2000). Regulation of ligand-induced heterodimerization and coactivator interaction by the activation function2 domain of the vitamin D receptor. Mol. Endocrinol. 14, 1776-1787. doi: 10.1210/mend.14.11.0560

Lokeshwar, B. L., Schwartz, G. G., Selzer, M. G., Burnstein, K. L., Zhuang, S. H., Block, N. L., et al. (1999). Inhibition of prostate cancer metastasis in vivo: a comparison of 1,25-dihydroxyvitamin D (calcitriol) and EB1089. Cancer Epidemiol. Biomarkers Prev. 8, 241-248.

Lundqvist, J., Hansen, S. K., and Lykkesfeldt, A. E. (2013). Vitamin D analog EB1089 inhibits aromatase expression by dissociation of comodulator WSTF from the CYP19A1 promoter-a new regulatory pathway for aromatase. Biochim. Biophys. Acta 1833, 40-47. doi: 10.1016/j.bbamcr.2012.10.012

Ma, Y., Yu, W. D., Hidalgo, A. A., Luo, W., Delansorne, R., Johnson, C. S., et al. (2013). Inecalcitol, an analog of 1,25D3, displays enhanced antitumor activity through the induction of apoptosis in a squamous cell carcinoma model system. Cell Cycle 12, 743-752. doi: 10.4161/cc.23846

Macejova, D., Ondkova, S., Jakubikova, L., Mlynarcikova, A., Scsukova, S., Liska, J., et al. (2011). MNU-induced mammary gland carcinogenesis: chemopreventive and therapeutic effects of vitamin D and Seocalcitol on selected regulatory vitamin D receptor pathways. Toxicol. Lett. 207, 60-72. doi: 10.1016/j.toxlet.2011.07.029

Matsumoto, T., Ito, M., Hayashi, Y., Hirota, T., Tanigawara, Y., Sone, T., et al. (2011). A new active vitamin D3 analog, eldecalcitol, prevents the risk of osteoporotic fractures-a randomized, active comparator, double-blind study. Bone 49, 605-612. doi: 10.1016/j.bone.2011.07.011

Milczarek, M., Psurski, M., Kutner, A., and Wietrzyk, J. (2013a). Vitamin D analogs enhance the anticancer activity of 5-fluorouracil in an in vivo mouse colon cancer model. BMC Cancer 13:294. doi: 10.1186/1471-2407-13-294 
Milczarek, M., Rosinska, S., Psurski, M., Maciejewska, M., Kutner, A., and Wietrzyk, J. (2013b). Combined colonic cancer treatment with vitamin D analogs and irinotecan or oxaliplatin. Anticancer Res. 33, 433-444.

Motomura, S., Kanamori, H., Maruta, A., Kodama, F., and Ohkubo, T. (1991). The effect of 1-hydroxyvitamin D3 for prolongation of leukemic transformationfree survival in myelodysplastic syndromes. Am. J. Hematol. 38, 67-68. doi: 10.1002/ajh.2830380112

Nakagawa, K., Sasaki, Y., Kato, S., Kubodera, N., and Okano, T. (2005). 22-Oxa-1alpha,25-dihydroxyvitamin D3 inhibits metastasis and angiogenesis in lung cancer. Carcinogenesis 26, 1044-1054. doi: 10.1093/carcin/ bgi049

Oades, G. M., Dredge, K., Kirby, R. S., and Colston, K. W. (2002). Vitamin D receptor-dependent antitumour effects of 1,25-dihydroxyvitamin D3 and two synthetic analogues in three in vivo models of prostate cancer. BJU Int. 90, 607-616. doi: 10.1046/j.1464-410X.2002.02964.X

Obara, W., Mizutani, Y., Oyama, C., Akaza, H., Ishii, N., Kohri, K., et al. (2008). Prospective study of combined treatment with interferon-alpha and active vitamin D3 for Japanese patients with metastatic renal cell carcinoma. Int. J. Urol. 15, 794-799. doi: 10.1111/j.1442-2042.2008.02086.x

O'Brien, M. E., Talbot, D., Maclennan, K., and Smith, I. E. (1993). Inefficacy of calcipotriol in skin metastases from breast cancer. Lancet 342, 994. doi: 10.1016/0140-6736(93)92042-R

Okamoto, R., Delansorne, R., Wakimoto, N., Doan, N. B., Akagi, T., Shen, M., et al. (2012). Inecalcitol, an analog of 1alpha, $25(\mathrm{OH})(2) \mathrm{D}(3)$, induces growth arrest of androgen-dependent prostate cancer cells. Int. J. Cancer 130, 2464-2473. doi: $10.1002 /$ ijc. 26279

Okamoto, R., Gery, S., Kuwayama, Y., Borregaard, N., Ho, Q., Alvarez, R., et al. (2014). Novel Gemini vitamin D3 analogs: large structure/function analysis and ability to induce antimicrobial peptide. Int. J. Cancer 134, 207-217. doi: $10.1002 / \mathrm{ijc} .28328$

Okano, T., Tsugawa, N., Masuda, S., Takeuchi, A., Kobayashi, T., and Nishii, Y. (1989a). Protein-binding properties of 22-oxa-1 alpha,25-dihydroxyvitamin D3, a synthetic analogue of 1 alpha,25-dihydroxyvitamin D3. J. Nutr. Sci. Vitaminol. (Tokyo) 35, 529-533. doi: 10.3177/jnsv.35.529

Okano, T., Tsugawa, N., Masuda, S., Takeuchi, A., Kobayashi, T., Takita, Y., et al. (1989b). Regulatory activities of 2 beta-(3-hydroxypropoxy)-1 alpha, 25-dihydroxyvitamin D3, a novel synthetic vitamin D3 derivative, on calcium metabolism. Biochem. Biophys. Res. Commun. 163, 1444-1449. doi: 10.1016/0006-291X(89)91140-6

Park, M. R., Lee, J. H., Park, M. S., Hwang, J. E., Shim, H. J., Cho, S. H., et al. (2012). Suppressive effect of 19-nor-1alpha-25-dihydroxyvitamin D2 on gastric cancer cells and peritoneal metastasis model. J. Korean Med. Sci. 27, 1037-1043. doi: 10.3346/jkms.2012.27.9.1037

Perez-Stable, C. M., Schwartz, G. G., Farinas, A., Finegold, M., Binderup, L., Howard, G. A., et al. (2002). The G gamma / T-15 transgenic mouse model of androgen-independent prostate cancer: target cells of carcinogenesis and the effect of the vitamin D analogue EB 1089. Cancer Epidemiol. Biomarkers Prev. 11, 555-563.

Petrini, M., Caracciolo, F., Corini, M., Valentini, P., Sabbatini, A. R., and Grassi, B. (1991). Low-dose ARA-C and 1(OH) D3 administration in acute non lymphoid leukemia: pilot study. Haematologica 76, 200-203.

Pommergaard, H. C., Burcharth, J., Rosenberg, J., and Raskov, H. (2013). Combination chemoprevention with diclofenac, calcipotriol and difluoromethylornithine inhibits development of non-melanoma skin cancer in mice. Anticancer Res. 33, 3033-3039.

Prudencio, J., Akutsu, N., Benlimame, N., Wang, T., Bastien, Y., Lin, R., et al. (2001). Action of low calcemic lalpha,25-dihydroxyvitamin D3 analogue EB1089 in head and neck squamous cell carcinoma. J. Natl. Cancer Inst. 93, 745-753. doi: 10.1093/jnci/93.10.745

Quack, M., and Carlberg, C. (1999). Selective recognition of vitamin D receptor conformations mediates promoter selectivity of vitamin D analogs. Mol. Pharmacol. 55, 1077-1087. doi: 10.1124/mol.55.6.1077

Raina, V., Cunningham, D., Gilchrist, N., and Soukop, M. (1991). Alfacalcidol is a nontoxic, effective treatment of follicular small-cleaved cell lymphoma. $\mathrm{Br}$. J. Cancer 63, 463-465. doi: 10.1038/bjc.1991.108

Sato, T., Takusagawa, K., Asoo, N., and Konno, K. (1984). Effect of 1 alphahydroxyvitamin D3 on metastasis of rat ascites hepatoma K-231. Br. J. Cancer 50, 123-125. doi: 10.1038/bjc.1984.148
Schwartz, G. G., Eads, D., Naczki, C., Northrup, S., Chen, T., and Koumenis, C. (2008). 19-nor-1 alpha,25-dihydroxyvitamin D2 (paricalcitol) inhibits the proliferation of human pancreatic cancer cells in vitro and in vivo. Cancer Biol. Ther. 7, 430-436. doi: 10.4161/cbt.7.3.5418

Schwartz, G. G., Hall, M. C., Stindt, D., Patton, S., Lovato, J., and Torti, F. M. (2005). Phase I/II study of 19-nor-1alpha-25-dihydroxyvitamin D2 (paricalcitol) in advanced, androgen-insensitive prostate cancer. Clin. Cancer Res. 11(24 Pt 1), 8680-8685. doi: 10.1158/1078-0432.CCR-05-1237

Schwinn, M. K., and DeLuca, H. F. (2007). Differential recruitment of coactivators to the vitamin $\mathrm{D}$ receptor transcriptional complex by 1alpha,25dihydroxyvitamin D3 analogs. Arch. Biochem. Biophys. 465, 443-451. doi: 10.1016/j.abb.2007.06.015

Seubwai, W., Wongkham, C., Puapairoj, A., Okada, S., and Wongkham, S. (2010). 22-oxa-1,25-dihydroxyvitamin D3 efficiently inhibits tumor growth in inoculated mice and primary histoculture of cholangiocarcinoma. Cancer 116, 5535-5543. doi: 10.1002/cncr.25478

Shalhoub, V., Shatzen, E. M., Ward, S. C., Young, J. I., Boedigheimer, M., Twehues, L., et al. (2010). Chondro/osteoblastic and cardiovascular gene modulation in human artery smooth muscle cells that calcify in the presence of phosphate and calcitriol or paricalcitol. J. Cell. Biochem. 111, 911-921. doi: 10.1002/jcb. 22779

Shankar, V. N., Dilworth, F. J., Makin, H. L., Schroeder, N. J., Trafford, D. J., Kissmeyer, A. M., et al. (1997). Metabolism of the vitamin D analog EB1089 by cultured human cells: redirection of hydroxylation site to distal carbons of the side-chain. Biochem. Pharmacol. 53, 783-793. doi: 10.1016/S00062952(96)00815-5

Shinaberger, C. S., Kopple, J. D., Kovesdy, C. P., McAllister, C. J., van Wyck, D., Greenland, S., et al. (2008). Ratio of paricalcitol dosage to serum parathyroid hormone level and survival in maintenance hemodialysis patients. Clin. J. Am. Soc. Nephrol. 3, 1769-1776. doi: 10.2215/CJN.01760408

So, J. Y., Lee, H. J., Smolarek, A. K., Paul, S., Wang, C. X., Maehr, H., et al. (2011). A novel Gemini vitamin D analog represses the expression of a stem cell marker CD44 in breast cancer. Mol. Pharmacol. 79, 360-367. doi: 10.1124/mol.110.068403

Sundaram, S., Sea, A., Feldman, S., Strawbridge, R., Hoopes, P. J., Demidenko, E., et al. (2003). The combination of a potent vitamin D3 analog, EB 1089, with ionizing radiation reduces tumor growth and induces apoptosis of MCF-7 breast tumor xenografts in nude mice. Clin. Cancer Res. 9, 2350-2356.

Teng, M., Wolf, M., Lowrie, E., Ofsthun, N., Lazarus, J. M., and Thadhani, R. (2003). Survival of patients undergoing hemodialysis with paricalcitol or calcitriol therapy. N. Engl. J. Med. 349, 446-456. doi: 10.1056/NEJMoa022536

Tentori, F., Hunt, W. C., Stidley, C. A., Rohrscheib, M. R., Bedrick, E. J., Meyer, K. B., et al. (2006). Mortality risk among hemodialysis patients receiving different vitamin D analogs. Kidney Int. 70, 1858-1865. doi: 10.1038/sj.ki.5001868

Trouillas, P., Honnorat, J., Bret, P., Jouvet, A., and Gerard, J. P. (2001). Redifferentiation therapy in brain tumors: long-lasting complete regression of glioblastomas and an anaplastic astrocytoma under long term 1-alphahydroxycholecalciferol. J. Neurooncol. 51, 57-66. doi: 10.1023/A:1006437003352

Uchiyama, Y., Higuchi, Y., Takeda, S., Masaki, T., Shira-Ishi, A., Sato, K., et al. (2002). ED-71, a vitamin D analog, is a more potent inhibitor of bone resorption than alfacalcidol in an estrogen-deficient rat model of osteoporosis. Bone 30, 582-588. doi: 10.1016/S8756-3282(02)00682-8

Valrance, M. E., Brunet, A. H., and Welsh, J. (2007). Vitamin D receptor-dependent inhibition of mammary tumor growth by EB1089 and ultraviolet radiation in vivo. Endocrinology 148, 4887-4894. doi: 10.1210/en.2007-0267

van den Bemd, G. C., Pols, H. A., Birkenhager, J. C., and van Leeuwen, J. P. (1996) Conformational change and enhanced stabilization of the vitamin $\mathrm{D}$ receptor by the 1,25-dihydroxyvitamin D3 analog KH1060. Proc. Natl. Acad. Sci. U.S.A. 93, 10685-10690. doi: 10.1073/pnas.93.20.10685

van Ginkel, P. R., Yang, W., Marcet, M. M., Chow, C. C., Kulkarni, A. D., Darjatmoko, S., et al. (2007). 1 alpha-Hydroxyvitamin D2 inhibits growth of human neuroblastoma. J. Neurooncol. 85, 255-262. doi: 10.1007/s11060-0079418-z

Vanoirbeek, E., Eelen, G., Verlinden, L., Marchal, K., Engelen, K., De Moor, B., et al. (2009). Microarray analysis of MCF-7 breast cancer cells treated with 1,25-dihydroxyvitamin D3 or a 17-methyl-D-ring analog. Anticancer Res. 29, 3585-3590.

VanWeelden, K., Flanagan, L., Binderup, L., Tenniswood, M., and Welsh, J. (1998). Apoptotic regression of MCF-7 xenografts in nude mice treated 
with the vitamin D3 analog, EB1089. Endocrinology 139, 2102-2110. doi: 10.1210/en.139.4.2102

Vegesna, V., O’Kelly, J., Said, J., Uskokovic, M., Binderup, L., and Koeffle, H. P. (2003). Ability of potent vitamin D3 analogs to inhibit growth of prostate cancer cells in vivo. Anticancer Res. 23, 283-289.

Wietrzyk, J., Nevozhay, D., Filip, B., Milczarek, M., and Kutner, A. (2007). The antitumor effect of lowered doses of cytostatics combined with new analogs of vitamin D in mice. Anticancer Res. 27, 3387-3398.

Wietrzyk, J., Nevozhay, D., Milczarek, M., Filip, B., and Kutner, A. (2008). Toxicity and antitumor activity of the vitamin D analogs PRI-1906 and PRI-1907 in combined treatment with cyclophosphamide in a mouse mammary cancer model. Cancer Chemother. Pharmacol. 62, 787-797. doi: 10.1007/s00280-0070666-6

Wietrzyk, J., Pelczynska, M., Madej, J., Dzimira, S., Kusnierczyk, H., Kutner, A., et al. (2004). Toxicity and antineoplastic effect of (24R)-1,24-dihydroxyvitamin D3 (PRI-2191). Steroids 69, 629-635. doi: 10.1016/j.steroids.2004.05.015

Wu-Wong, J. R., Nakane, M., Ma, J., Ruan, X., and Kroeger, P. E. (2007). VDRmediated gene expression patterns in resting human coronary artery smooth muscle cells. J. Cell. Biochem. 100, 1395-1405. doi: 10.1002/jcb.21133

Yamamoto, H., Shevde, N. K., Warrier, A., Plum, L. A., DeLuca, H. F., and Pike, J. W. (2003). 2-Methylene-19-nor-(20S)-1,25-dihydroxyvitamin D3 potently stimulates gene-specific DNA binding of the vitamin D receptor in osteoblasts. J. Biol. Chem. 278, 31756-31765. doi: 10.1074/jbc.M304737200

Yoon, J. S., Kim, J. Y., Park, H. K., Kim, E. S., Ahn, K. S., Yoon, S. S., et al. (2008). Antileukemic effect of a synthetic vitamin D3 analog, HY-11, with low potential to cause hypercalcemia. Int. J. Oncol. 32, 387-396. doi: 10.3892/ijo.32.2.387
Zella, L. A., Meyer, M. B., Nerenz, R. D., and Pike, J. W. (2009). The enhanced hypercalcemic response to 20-epi-1,25-dihydroxyvitamin D3 results from a selective and prolonged induction of intestinal calcium-regulating genes. Endocrinology 150, 3448-3456. doi: 10.1210/en. 2009-0113

Zhang, X., Jiang, F., Li, P., Li, C., Ma, Q., Nicosia, S. V., et al. (2005). Growth suppression of ovarian cancer xenografts in nude mice by vitamin $\mathrm{D}$ analogue EB1089. Clin. Cancer Res. 11, 323-328.

Conflict of Interest Statement: The authors declare that the research was conducted in the absence of any commercial or financial relationships that could be construed as a potential conflict of interest.

Received: 06 February 2014; paper pending published: 19 February 2014; accepted: 13 March 2014; published online: 03 April 2014.

Citation: Leyssens C, Verlinden L and Verstuyf A (2014) The future of vitamin D analogs. Front. Physiol. 5:122. doi: 10.3389/fphys.2014.00122

This article was submitted to Integrative Physiology, a section of the journal Frontiers in Physiology.

Copyright (c) 2014 Leyssens, Verlinden and Verstuyf. This is an open-access article distributed under the terms of the Creative Commons Attribution License (CC BY). The use, distribution or reproduction in other forums is permitted, provided the original author(s) or licensor are credited and that the original publication in this journal is cited, in accordance with accepted academic practice. No use, distribution or reproduction is permitted which does not comply with these terms. 